\title{
Eğitim Fakültesi Öğrencilerinin Uzaktan Ĕ̆itime Karşı Tutumlarının ve E-Öğrenmeye Hazır Bulunuşluklarının Incelenmesi
}

\section{Investigation of Attitudes towards Distance Education and Readiness for E-Learning of Education Faculty Students}

\author{
Levent YAKAR*, Züleyha YILDIRIM YAKAR**
}

\begin{abstract}
Öz: Yeni Koronavirüs (Covid-19) olarak adlandırılan virüs salgını nedeniyle birçok ülkede olduğu gibi Türkiye'de de eğitimler uzaktan eğitimle yürütülmeye başlandı. Bu araştırmada, örgün öğrenime kayıtlı olduğu halde bu salgın döneminde uzaktan eğitim alma durumunda kalan eğitim fakültesi öğrencilerinin uzaktan eğitime karşı tutumları ve e-öğrenmeye hazır bulunuşlukları çeşitli değişkenler bağlamında incelenmiş̧tir. Betimsel tarama niteliğindeki araştırmanın katılımcılarını Kahramanmaraş Sütçü İmam Üniversitesi (KSÜ) Eğitim Fakültesinin farklı bölümlerinde öğrenim gören toplam 333 öğrenci oluşturmaktadır. Araştırmada veri toplama aracı olarak "E-Öğrenmeye Hazır Bulunuşluk Ölçeğì" ve "Uzaktan Eğitime Karşı Tutum Ölçeği”" kullanılmıştır. Verilerin analizinde betimsel istatistikler, normal dağılım varsayımlarının karşılanma durumuna göre Kruskall Wallis, Mann Whitney U, bağımsız örneklem $\mathrm{t}$ testi ve Anova testleri kullanılmıştır. Araştırmada öğrencilerin uzaktan eğitime karşı tutumlarının kararsız seviyeye yakın olumsuz, e-öğrenmeye hazır bulunuşluk seviyelerinin ise yükseğe yakın olmakla beraber orta düzeyde olduğu görülmüştür. Öğrencilerin tutumları üzerinde sınıf düzeyi, bölüm, bilgisayar ve internet değişkenlerinin etkili olduğu, e-öğrenme hazır bulunuşlukları üzerinde ise sınıf düzeyi, bilgisayar, internet, akıllı telefon ve deneyim değişkenlerinin etkili olduğu belirlenmiştir. Araştırmanın bir diğer sonucuna göre ise uzaktan eğitime karşı tutum ile e-öğrenmeye hazır bulunuşluk arasında orta düzeyde ilişki vardır. E-öğrenmeye hazır bulunuşluk yapısının alt boyutları bakımından ise uzaktan eğitime karşı tutum ile motivasyon boyutu arasında yüksek düzeyde ilişki bulunmuştur.
\end{abstract}

Anahtar Kelimeler: Uzaktan eğitim, e-öğrenme, tutum, hazır bulunuşluk, eğitim fakültesi öğrencileri.

\begin{abstract}
Due to the virus outbreak caused by novel Coronavirus (Covid-19), education began to be carried out in Turkey via distance education as many countries worldwide. In this study, the attitudes towards to distance education and readiness for e-learning of education faculty students who were registered to formal education but had to take distance education during this epidemic period were examined in the context of the variables that are thought to be relevant. The participants of the descriptive survey research consisted of 333 students studying in different departments of the Faculty of Education of Kahramanmaraş Sütçü İmam University (KSU). The e-learning readiness scale and the attitude towards distance education scale were used as data collection tools. In the analysis of the data, descriptive statistics, Kruskall Wallis, Mann Whitney U, independent sample t test and Anova tests were used. In the study, it was observed that students' attitudes towards distance education was low level close to moderate and their readiness was to e-learning was moderate level close to high. It was determined that class level, having computer, internet, smart phone and experience variables were effective on e-learning readiness and grade, department, having computer and internet variables were effective on students' attitudes. According to another result of the research, there is a moderate level relationship between attitude towards distance education and readiness to e-learning. In terms of the sub-dimensions of the e-learning readiness structure, a high level of relation was found between the attitude towards distance education and the motivation.
\end{abstract}

Keywords: Distance education, e-learning, attitude, readiness, education faculty students.

\section{Giriş}

Eğitim kapsamı, yapısı ve işlevi itibariyle toplumsal sorunlardan en fazla etkilenen ve değişikliğe uğrayan alanlardan biridir. Bu durumun son örneği olarak, Çin'in Vuhan şehrinde 1 Aralık 2019 tarihinde ortaya çıkan ve yeni Koronavirüs (Covid-19) olarak adlandırılan virüs salgını nedeniyle

*Dr. Öğr. Üyesi, Kahramanmaraş Sütçü İmam Üniversitesi, Eğitim Fakültesi, Kahramanmaraş-Türkiye, ORCID: 00000001-7856-6926, e-posta: 1_yakar@hotmail.com

**Dr. Öğr. Üyesi, Kahramanmaraş Sütçü İmam Üniversitesi, Eğitim Fakültesi, Kahramanmaraş-Türkiye, ORCID: 0000-0002-6420-2205, e-posta: zuleyhayildirim@ksu.edu.tr

Gönderi Tarihi:15.08.2020 - Kabul Tarihi: 26.11.2020 
Türkiye'nin de aralarında bulunduğu birçok dünya ülkesinde yüz yüze eğitime ara verilmesi ve uzaktan eğitim hizmetlerinin verilmeye başlanması gösterilebilir. Tüm dünyayı etkisi altına alarak hayatı durma noktasına getiren bu küresel salgın sebebiyle, Türkiye'de 23 Mart 2020 tarihinden itibaren tüm eğitim kademelerinde derslerin TV ve internet kanalları üzerinden uzaktan öğretimle yürütülmesi kararlaştırılmıştır (Milli Eğitim Bakanlığ [MEB], 2020; Yüksek Öğretim Kurumu [YÖK], 2020). Bu süreçte örgün eğitim yapılandırılmasının tek başına toplumların eğitim gereksinimlerini karşılamada yetersiz olduğunun anlaşılmasıyla birlikte eğitim sistemlerinin uzaktan eğitim hizmeti verebilecek şekilde yapılandırılmasının ne kadar önemli bir konu olduğu tekrar ortaya çıkmıştır.

Ülkemizde yüz yüze eğitimin verilemediği bu süreçte üniversitelerin uzaktan eğitim uygulamalarına başlayabilmesi için gerekli alt yapının ve içeriğin oluşturulması yönünde çalışmalara hız verilmiştir. Birçok üniversite, uzaktan eğitim uygulama ve araştırma merkezlerinin bulunması ve bu merkezler bünyesinde uzaktan eğitim yoluyla ön lisans, lisans ve yüksek lisans programlarında eğitim vermeleri (Yavuzalp, Demirel, Taş ve Canbolat, 2017) ve sadece uzaktan eğitim uygulamalarında değil geleneksel öğretimde de internet yoluyla öğrenme anlamına gelebilen e-öğrenme olanaklarından yararlanmaları sayesinde bu sürece kolaylıkla adapte olabilmiştir. Uzaktan eğitim için gerekli alt yapı ve içerik eksikliği olan üniversiteler de sürece dâhil olabilmek için uzaktan eğitim deneyimi olan üniversitelerle birlikte işbirliği çalışmaları yürüterek öğrencilerine uzaktan eğitim hizmeti vermeye başlamışlardır. Üniversitelerin e-öğrenme için alt yapı, içerik ve insan kaynakları noktasında yeterli donanımda olmaları uzaktan eğitim sürecinin başlayabilmesinde en önemli adımı oluştursa da tek başına uzaktan eğitimin etkililiğinin göstergesi değildir (Demir, 2015). E-öğrenme sisteminin yönetimi, öğrenme platformu ve kaynakları, eğitimcilerin pedagojik yaklaşımı, bilgi ve becerileri, öğrenenlerin bilgi/beceri ve duyuşsal özellikleri gibi birçok unsur uzaktan eğitim uygulamalarının niteliği üzerinde belirleyicidir (Persico, Manca ve Pozzi, 2014). Dolayısıyla sadece kurumların ve eğitimcilerin uzaktan eğitime hazır olmaları değil bu olağandışı sürece kadar geleneksel yüz yüze eğitim yaklaşımlarıyla örgün eğitime devam eden öğrencilerin e-öğrenmeye hazır bulunuşlukları ve uzaktan eğitime yönelik tutumları sürecin etkililiği ve verimliliği üzerinde belirleyici olacaktır.

E-öğrenme uygulaması teknoloji ve kendi kendine öğrenme becerisine bağlı olduğundan öğrenmenin sorumluluğu büyük oranda öğrencilere aittir (Karaoğlan-Y1lmaz, 2016). Ancak eöğrenme ile uzaktan eğitim sürecinde öğrenciler birçok problemle karşılaşmakta ve bu süreçte dişsal desteğe ihtiyaç duymaktadırlar (Yurdugül ve Demir, 2017). Uzaktan eğitimin e-öğrenme ile birlikte sağlanması öğrenciler açısından ekonomik, eğitsel ve teknolojik birtakım sorunları beraberinde getirebilmektedir. Katılımcıların gerekli donanıma sahip olmamaları, söz konusu teknolojileri kullanmada gerekli bilgi, beceri ve tutumlara sahip olmamaları ve öğrencilerin etkileşimleri sırasında ses, görüntü ya da bağlantının kesilmesi gibi sorunlar öğrenmeyi engelleyebilmekte, öğrenme güdüsünü ve isteğini azaltabilmektedir (Yurdakul, 2019). Bu nedenle uzaktan eğitim sisteminde dikkate alınması gereken en önemli öğrenci özelliklerinin başında e-öğrenmeye hazır bulunuşluk ve tutum olduğu söylenebilir. E-öğrenmenin, geleneksel öğrenmeye göre öğrencilere kendi bireysel seviyelerinde ilerleme ve istenildiği kadar tekrar yapma olanağı sağlama, görüntülü ve sesli etkileşime olanak verme, daha fazla sayıda öğrenciye ulaşabilme ve zamandan ve mekândan bağımsız eğitim alma olanağı sunma gibi üstünlüklerinden (Oral, 2017) yararlanılabilmesi için öğrencilerin e-öğrenmeye hazır olmaları ve olumlu tutuma sahip olmaları sağlanmalıdır (Yurdugül ve Alsancak-Sırakaya, 2013).

Alan yazında hazır bulunuşluk ve tutumun tanımları incelendiğinde, benzer noktaları olmakla birlikte farklı kavramlar oldukları anlaşılmaktadır. Eğitsel açıdan hazır bulunuşluk, bir eğitim uygulaması için gerekli olan bilgi/beceri ve duyuşsal özelliklere sahip olma durumudur (Senemoğlu, 2009). E-öğrenme özelinde ise hazır bulunuşluk; öğrenenlerin, e-öğrenme içerik ve materyalleri ile çoklu ortam araçlarından en iyi şekilde yararlanabilme yetenekleri (Kaur ve Abas, 
2004), e-öğrenme deneyim ve eylemleri için zihinsel ve fiziksel açıdan hazırlıklı olma (Borotis ve Poulymenakou, 2004) şeklinde tanımlanabilmektedir. Tutum ise bir kişinin herhangi bir eşya, olay ve insan grubuna yönelik, olumlu veya olumsuz davranış gösterme eğilimidir (Turgut ve Baykul, 2010). Tutumlar, birbirleriyle karş1lıklı etkileşim içinde olan bilişsel, duyuşsal ve davranışsal olmak üzere üç öğeden oluşmaktadır. Buna göre, bireyin bir konuyla ilgili sahip olduğu düşünceleri, inançları, bilgi yapıları (bilişsel öğe), konuya karşı duygularını (duyuşsal öğe) şekillendirir. Sonuç olarak bireyin bu düşünce ve duyguları doğrultusunda tutum nesnesine ilişkin olumlu ya da olumsuz yönde davranış eğilimi (davranışsal öğe) meydana gelir (Tavşancıl, 2002). $\mathrm{Bu}$ anlamda öğrencilerin herhangi bir öğretim uygulamasına karşı ön bilgi/beceri ve duyuşsal özellik bakımından hazır bulunuşluklarının bu uygulamaya ilişkin tutumlarını da etkileyeceği söylenebilir. Bu nedenle mevcut çalışmada yüz yüze eğitim aldığı halde Koronavirüs salgını nedeniyle uzaktan eğitimle ders alma durumunda kalan öğrencilerin süreç başlamadan önceki eöğrenmeye hazır bulunuşlukları ve tutumları birlikte tespit edilmeye çalışılmıştır. Böylelikle öğrenme sorumluluğunu üstlenmek zorunda kalan öğrencilerin bu süreçte ne kadar aktif katılım sağlayabilecekleriyle ilgili daha kapsamlı değerlendirmeler yapılabileceği düşünülmektedir.

Alan yazında, uzaktan eğitim uygulamalarını ifade etmek için birbirinin yerine kullanılabilen uzaktan eğitim, e-öğrenme, çevrimiçi öğrenme, internet tabanlı öğretim, internette eğitim, web destekli öğretim gibi kavramlar (Özkul ve Aydın, 2012) altında üniversite öğrencilerinin hazır bulunuşluğunu (Alsancak-Sırakaya ve Yurdugül, 2016; Çakır ve Horzum, 2015; Horzum, 2019; Mercan, 2018; Sakal, 2017; Y1lmaz, Sezer ve Yurdugül, 2019; Yurdugül ve Demir, 2017) ve tutumlarını inceleyen çalışmalar mevcuttur (Dikbaş, 2006; Göksu ve Atmaca, 2019; Haznedar, 2012; Yenilmez, Turgut ve Balbağ, 2017; Yıldız, 2016). Ancak birbiri ile ilişkili olduğu düşünülen, öğrencilerin uzaktan eğitime yönelik tutumları ile e-öğrenmeye hazır bulunuşluklarını birlikte inceleyen çok sınırlı sayıda çalışmanın bulunması (Akgün, 2015; Yağcı, AlsancakSırakaya ve Özüdoğru, 2015) alan yazında bu yönde yapılmış çalışma ihtiyacı olduğunu göstermektedir. Ulaşılan bu çalışmalardan Yağc1, Alsancak-Sırakaya ve Özüdoğru'nun (2015) çalışmasının sadece bilgisayar eğitimi ve teknoloji öğretimi bölümünde öğrenim gören öğretmen adayları üzerinde, Akgün'ün(2015) çalışmasının ise uzaktan eğitim gören öğrenciler üzerinde yürütüldüğü görülmüştür. Bu nedenle örgün öğrenim gören öğretmen adaylarının uzaktan eğitim tutumlarının ve e-öğrenmeye hazır buluşluklarının birbiri ile ilişkilerinin ve bağlantılı olduğu değişkenlere göre düzeylerinin incelendiği bu çalışma ile alan yazına katkı sunulmaya çalışılmıştır.

Küresel Koronavirüs salgınından dolayı tüm eğitim kurumlarında uzaktan eğitime geçilmesiyle birlikte uzaktan eğitimin son derece önemli olduğunun anlaşıldığ1 günümüzde, üniversite öğrencilerinin e-öğrenmeye hazır bulunuşluklarının ve uzaktan eğitim tutumlarının tespit edildiği bu çalışma hâlihazırda verilen veya gelecekte verilmesi planlanan uzaktan eğitim faaliyetlerinin işlevselliğinin değerlendirilmesi açısından oldukça önemlidir. Çalışmanın, bundan sonraki süreçte örgün eğitim bünyesinde farklı nedenlerle kullanılacak uzaktan eğitimden etkili şekilde yararlanılması amacıyla, kurumsal anlamda yapılacak iyileştirme çalışmalarına önemli katkıları olacağı düşünülmektedir. Yükseköğretimde örgün eğitimin tamamlayıcısı olarak uzaktan eğitimin kullanımının giderek daha da artacağı düşünüldüğünde uzaktan eğitim uygulamasında öğrencilerin tutumlarının ve e-öğrenmeye hazır bulunuşluk incelenmesi, gerek kurumsal düzeyde yapılacak çalışmalar için gerekse de akademik alanda yapılacak çalışmalar için önemli görülmektedir. Çalışmanın örneklemini oluşturan öğretmen adaylarının uzaktan eğitime yönelik tutum ve e-öğrenmeye hazır bulunuşluk düzeylerinin belirlenmesi, ilerde meslek hayatlarında uzaktan eğitimi bir öğretim şekli olarak benimseme ve uygulayabilme düzeylerinin göstergelerinden olması bakımından ayrıca önemlidir. Tüm bu nedenlerle çalışmada, Kahramanmaraş Sütçü İmam Üniversitesi (KSÜ) eğitim fakültesi öğrencilerinin uzaktan eğitim tutum ve e-öğrenmeye hazır bulunuşluklarının birlikte ve farklı değişkenlere göre incelenmesi amaçlanmıştır. Bu amaç doğrultusunda aşağıdaki sorulara yanıt aranmıştır: 
1. Öğrencilerin uzaktan eğitime yönelik tutum ve e-öğrenmeye hazır bulunuşluk düzeyleri nedir?

2. Öğrencilerin uzaktan eğitime yönelik tutumları ve e-öğrenmeye hazır bulunuşluk düzeyleri cinsiyet, yaş, sınıf, bölüm, bilgisayar, internet, akıllı telefon ve deneyim değişkenlerine göre farklılaşmakta mıdır?

3. Öğrencilerin uzaktan eğitime yönelik tutum ve e-öğrenmeye hazır bulunuşluk düzeyleri arasında anlamlı bir ilişki var mıdır?

\section{Yöntem}

Betimsel nitelikteki bu araştırmada, üniversite öğrencilerinin uzaktan eğitime yönelik tutum ve eöğrenmeye hazır bulunuşluklarının birbirleri ile ve ilgili değişkenlerle ilişkisini belirlemek amacıyla tarama modeli kullanılmıştır. Tarama modelinde, geçmişte ya da halen var olan bir durum var olduğu şekliyle betimlenmeye çalışılır (Karasar, 2012).

\section{Çalışma grubu}

$\mathrm{Bu}$ araştırmanın çalışma evrenini KSÜ Eğitim Fakültesinde bulunan 22 şubede öğrenim gören 1214 öğrenci oluşturmaktadır. Bu öğrencilerin tümüne ulaşılmaya çalışıldığından, örneklem alma ihtiyacı duyulmamıştır. Ancak 17 şubedeki yaklaşık bin öğrenciye araştırma sorularını yanıtlamaları için bilgilendirici davetiye gönderilebilmiştir. Araştırmaya katılmaya gönüllü olan 338 öğrenci araştırma sorularına yanıt vermiştir. Ancak 5 katılımcının yanıtları çelişkili olması veya uç değerde yer alması dolayısıyla değerlendirmeye alınmamıştır. Dolayısıyla bu araştırmanın katılımcılarını 2019-2020 akademik yılının bahar döneminde KSÜ Eğitim Fakültesinde herhangi bir programa kayıtlı olan 333 öğrenci oluşturmaktadır. Aşağı da Tablo 1'de araştırmada kullanılan demografik değişkenlere göre katılımcıların dağılımları yer almaktadır.

Tablo 1

Katılımcıların Demografik Değişkenlere Göre Dağılımı

\begin{tabular}{|c|c|c|c|c|c|c|c|}
\hline Değişken & Grup & $\mathrm{f}$ & $\%$ & Değişken & Grup & $\mathrm{f}$ & $\%$ \\
\hline \multirow[t]{2}{*}{ Cinsiyet } & Kadın & 258 & 77,5 & \multirow[t]{4}{*}{ Sinif } & 1 & 85 & 25,5 \\
\hline & Erkek & 75 & 22,5 & & 2 & 82 & 24,6 \\
\hline \multirow[t]{6}{*}{ Bölüm* } & \multirow{6}{*}{$\begin{array}{l}\text { Matematik } \\
\text { Fen B. } \\
\text { Sinıf } \\
\text { Sosyal B. } \\
\text { İngilizce } \\
\text { Rehberlik }\end{array}$} & \multirow{3}{*}{$\begin{array}{l}58 \\
34\end{array}$} & \multirow[b]{2}{*}{17,4} & & 3 & 119 & 35,7 \\
\hline & & & & & 4 & 47 & 14,1 \\
\hline & & & $\begin{array}{l}10,2 \\
12,9\end{array}$ & \multirow[t]{4}{*}{ Yaş } & 18 ve altı & 12 & 3,6 \\
\hline & & 54 & 16,2 & & $19-21$ & 216 & 64,9 \\
\hline & & 6 & 1,8 & & $22-24$ & 91 & 27,3 \\
\hline & & 62 & 18,6 & & 25 ve üzeri & 14 & 4,2 \\
\hline \multirow[t]{2}{*}{ Bilgisayar } & Yok & 164 & 49,2 & \multirow[t]{2}{*}{ Ak1llı Telefon } & Yok & 11 & 3,3 \\
\hline & Var & 169 & 50,8 & & Var & 322 & 96,7 \\
\hline \multirow[t]{2}{*}{ İnternet } & Yok & 136 & 40,8 & \multirow[t]{2}{*}{ Deneyim } & Yok & 167 & 50,2 \\
\hline & Var & 197 & 59,2 & & Var & 166 & 49,8 \\
\hline
\end{tabular}

Not. * Dört katılımcı bölüm bilgisini girmemiştir.

Tablo 1'den anlaşılacağı gibi bölüm değişkeni hariç diğer tüm değişkenler için frekans toplamı 333'dür. Tablo 1'e göre katılımcıların büyük bir çoğunluğu kadınlardan $(\% 77,5)$ oluşmaktadır. Bunun nedeni KSÜ eğitim fakültesinde öğrenim gören kadın öğrencilerin sayısının erkek öğrencilerden fazla olmasıdır. İngilizce bölümünden katılımın oldukça düşük olması $(\% 1,8)$ ise, bu bölümde öğrenim gören öğrenci sayısının azlığından kaynaklanmaktadır. Ayrıca en fazla katılımın üçüncü sınıf düzeyinde $(\% 35,7)$, en az katılımın ise en az sayıda şubeye sahip olan dördüncü sınıf düzeyinde $(\% 14,1)$ gerçekleştiği anlaşılmaktadır. Öğrenci ve şubelerin yaklaşık \%80'ine ulaş1lması sayesinde, katılımcıların cinsiyet, bölüm ve sınıf değişkenlerine göre dağılımlarının fakültedeki tüm öğrencilerdeki dağılımlarıyla genel olarak uyumlu olduğu söylenebilir. 


\section{Veri toplama araçları}

Araştırmada veri toplama aracı olarak üç bölümden oluşan çevrimiçi ölçme aracı kullanılmıştır. Ölçme aracının birinci bölümünde demografik bilgiler formu, ikinci bölümünde Yurdugül ve Demir (2017) tarafından geliştirilen E-Öğrenmeye Hazır Bulunuşluk ölçeği, son bölümünde ise Ağır (2007) tarafından geliştirilen Uzaktan Eğitime Karşı Tutum ölçeği maddeleri yer almaktadır.

\section{Demografik bilgi formu}

Hazırlanan bu form ile araştırmaya katılan öğrencilerin cinsiyet, yaş, öğrenim gördükleri bölüm, sınıf düzeyi, uzaktan eğitim deneyimleri ve bilgisayar, internet ve akıllı telefona sahip olma durumları gibi bilgileri elde edilmeye çalışılmıştır.

\section{E-öğrenmeye hazır bulunuşluk ölçeği}

Yurdugül ve Demir (2017) tarafından geliştirilen E-Öğrenmeye Hazır Bulunuşluk ölçeği öğrenci formu 33 maddeden oluşmaktadır. Yedili likert tipi maddelerin kullanıldığı ölçekten 33-231 arası puan alınabilmekte ve puanın yükselmesi hazır bulunuşluğun yükseldiği anlamına gelmektedir. Ölçekte bilgisayar öz-yeterliği, internet öz-yeterliği, çevrimiçi iletişim öz-yeterliği, kendi kendine öğrenme, öğrenen kontrolü ve e-öğrenmeye yönelik motivasyon olmak üzere altı faktör bulunmaktadır. Geliştirme çalışmasında alt-boyutlar için Cronbach alfa güvenirlik katsayıları 0,84 ile 0,95 arasında, genel Cronbach alfa güvenirlik katsayısı ise 0,93 bulunmuştur. $\mathrm{Bu}$ çalışmada ise ölçeğin alt-boyutlar için Cronbach alfa güvenirlik katsayıları 0,91 ile 0,95 arasında, tabakalı Cronbach alfa genel güvenirlik katsayısı ise 0,98 bulunmuştur. Ayrıca ölçeğin faktör yapısı doğrulayıcı faktör analizi ile test edilmiş ve uyum indeksleri $X^{2} / \mathrm{sd}=3,02, \mathrm{RMSEA}=0,079$, $\mathrm{NFI}=0,96, \mathrm{CFI}=0,98$ olarak bulunmuştur. Uyum indekslerinin mükemmel uyuma işaret etmesi ölçeğin faktör yapısının doğrulandığını göstermektedir (Çokluk, Şekercioğlu ve Büyüköztürk, 2014).

\section{Uzaktan ĕgitime karşı tutum ölçeği}

Ağır (2007) tarafından geliştirilen Uzaktan Eğitime Karş1 Tutum ölçeği 21 maddeden oluşmaktadır. Beşli likert tipi maddelerin kullanıldığı ölçekten 21-105 arası puan alınabilmekte ve puanın yükselmesi uzaktan eğime karşı daha olumlu tutum olduğu anlamına gelmektedir. Ölçeğin Cronbach Alfa güvenirlik katsayısı 0,93 bulunmuştur. Ölçeğin güvenirlik katsayısı bu çalışmada da hesaplanmış ve Cronbach Alfa güvenirlik katsayısı 0,94 olarak bulunmuştur. Ölçeğin geliştiricisi faktör yapısı hakkında yeteri kadar bilgi vermediği için, ölçek toplam puan üzerinden kullanılmış ve doğrulayıcı faktör analizi gerçekleştirilememiştir.

\section{İşlem}

Verilerin toplanabilmesi için Kahramanmaraş Sütçü İmam Üniversitesi Sosyal ve Beşeri Bilimler Etik Kurulundan 72321963-044 sayılı yazı ile etik kurul izni alınmıştır. Araştırma verileri 20192020 akademik yılının bahar döneminde Covid-19 salgını nedeniyle eğitime verilen aranın ardından uzaktan eğitime geçilen haftanın hemen öncesinde toplanmaya başlanmıştır. Veriler 2227 Mart 2020 tarihleri arasında toplanmıştır. Katılımcılara ulaşmak adına e-posta gönderilerek çalışmanın amacına ilişkin açıklamada bulunulmuş ve mailde bulunan Google formlar adresindeki maddeleri yanıtlamaları istenmiştir. E-posta gönderilen öğrencilerin yaklaşık üçte biri gönüllü olarak katılım sağlayarak maddeleri yanıtlamışlardır. Formda bulunan tüm soruların yanıtlanmasının zorunlu tutulmasıyla kayıp veri oluşmasının önüne geçilmiştir. Veri analizleri 333 yanıttan elde edilen veriyle gerçekleştirilmiştir.

\section{Verilerin analizi}

Google formlar aracılığıyla 350 yanıt alınmıştır. Yanıtlar incelendiğinde 12 kişinin iki kez yanıt verdiği görüldüğünden bu kişilerin birer yanıtları silinmiştir. Geri kalan veriler incelendiğinde bir kişinin çelişkili yanıt verdiği düşünüldüğünden değerlendirmeye alınmamıştır. Geri kalan 337 bireyin verdiği yanıtlardan oluşan veriler SPSS 23.0 istatistik programı ile çözümlenmiştir. Veride bulunabilecek olası tek değişkenli uç değerleri bulmak için $\mathrm{z}$ standart puanları 
hesaplanmıştır. Tüm z standart puanlarının $(-3,29$ - 3,29) aralığında olduğu görülmüştür (Tabachnick ve Fidell, 2007). Olası çok değişkenli uç değerler için Mahalanobis uzaklıkları incelenmiş ve Mahalanobis değerleri $p=0,001$ için verilen ki-kare değerinin üstünde olan dört bireyin yanıtlarının veriden çıkarılmasına karar verilmiştir (Tabachnick ve Fidell, 2007). Kalan 333 bireyin yanıtları üzerinden analizler gerçekleştirilmiştir.

Öncelikle ölçeklerin her biri için normal dağılım varsayımı kontrol edilmiştir. Varsayımın testi için her bir ölçekten elde edilen puanların çarpıklık, basıklık katsayıları, Q, Q plot - normallik eğrisi çizilmiş histogram yöntemleri kullanılmıştır. Az sayıda bireyin yer aldığı alt grup barındıran bölüm, yaş ve akıllı telefon değişkenlerinde normal dağılım varsayımları karşılanamadığı için parametrik olmayan istatistik yöntemlerinden Kruskall Wallis ve Mann Whitney U istatistikleri kullanılmıştır. Diğer değişkenlerin alt gruplarında da normal dağılım varsayımlarının karşılandığ görülmüş ve bu değişkenler göre ölçek puanlarının değişip değişmediği bağımsız örneklem t testi ve ANOVA ile analiz edilmiştir. Yapılan ANOVA sonrasında ilgili değișken için varyans eşitliğinin sağlanması nedeniyle ikili karşılaştırmalarda Tukey testi tercih edilmiştir. MannWhitney U, Kruskall Wallis ve bağımsız örneklem $t$ testlerinde gruplar arası görülen farkın büyüklüğünün tespiti için Cohen'in d etki büyüklüğü istatistiği kullanılmıştır. Cohen'in d değerinin 0-0,2 arasında olması zayıf, 0,21 - 0,5 arasında olması düşük ve 0,51 - 1,00 arasında olması orta, 1,00'in üzerinde olması ise güçlü etkiye işaret etmektedir (Cohen, Manion ve Morrison, 2007). ANOVA'da ise kısmi eta kare $\eta^{2}$ etki büyüklüğü 0,01 küçük, 0,06 orta ve 0,14 büyük etki büyüklüğü olarak raporlanmıştır (Cohen, 1988). Son olarak ölçekler arası ilişkinin incelenmesinde Pearson korelasyon katsayısı kullanılmıştır.

\section{Bulgular}

Bu bölümde araştırma kapsamında elde edilen bulgular araştırma sorularına göre temel başlıklar altında sırayla verilmiştir.

\section{UEKT ve EÖHB düzeyleri}

Araştırmada kullanılan uzaktan eğitime karşı tutum (UEKT) ölçeği, E-Öğrenmeye Hazır Bulunuşluk ölçeği (EÖHB) ve EÖHB alt boyutlarına ilişkin betimsel istatistikler Tablo 2'de sunulmuştur.Tablo 2'ye göre UEKT ölçeğinde öğrencilerin genel puan ortalamas1 53,64 ve madde ortalama puan değeri 2,55'dir. Bu ölçek için maddelerin ortalama puan değerinin 1-5 arasında olduğu düşünüldüğünde katılımcıların uzaktan eğitime karşı tutumlarının kararsız seviyeye yakın olumsuz olduğu söylenebilir. Öğrencilerin EÖHB ölçeğinden elde ettikleri ortalama puan değeri ise 148,15 ve madde ortalama puan değeri 7 üzerinden 4,49'dur. Bu değer öğrencilerin e-öğrenmeye hazır bulunuşluk düzeylerinin orta seviyede olduğunu göstermektedir. Tablo 2'de verilen EÖHB ölçeğinin alt boyut değerlerine göre öğrencilerin hazır bulunuşluk düzeylerinin internet öz yeterliği, öğrenen kontrolü ve kendi kendine öğrenme boyutlarında yüksek, bilgisayar öz yeterliği ve çevrimiçi iletişim öz yeterliği boyutlarında ise orta düzeyde olduğu anlaşılmaktadır. Öğrencilerin e-öğrenmeye yönelik motivasyon düzeylerinin ise düşük olduğu görülmektedir.

Tablo 2

UEKT ve EÖHB Ölçek Verilerine İlişkin Betimsel İstatistikler

\begin{tabular}{lrrrrr}
\hline Ölçek & Ölçek Ort. & Std. Sapma & Madde Ort. & Çarpıklık & Basıklık \\
\hline UEKT & 53,64 & 14,94 & 2,55 & 0,091 & $-0,033$ \\
EÖHB & 148,15 & 39,10 & 4,49 & $-0,360$ & $-0,610$ \\
Bilgisayar Öz-Yeterliği & 19,72 & 7,72 & 3,94 & $-0,071$ & $-0,907$ \\
İnternet Öz-Yeterliği & 21,84 & 5,88 & 5,46 & $-0,869$ & $-0,155$ \\
Çevrimiçi İletişim Öz-Yeterliği & 22,45 & 7,93 & 4,49 & $-0,306$ & $-0,894$ \\
Kendi Kendine Öğrenme & 40,43 & 9,94 & 5,05 & $-0,548$ & $-0,272$ \\
Öğrenen Kontrolü & 20,41 & 5,72 & 5,10 & $-0,642$ & $-0,114$ \\
E-Öğrenmeye Yönelik Motivasyon & 23,30 & 12,07 & 3,33 & 0,341 & $-1,040$ \\
\hline
\end{tabular}


Tablo 2'de bulunan çarpıklık ve basıklık değerleri incelendiğinde, e-öğrenmeye yönelik motivasyon alt boyutu hariç tüm ölçek ve alt boyutlarda çarpıklık ve basıklık değerlerinin-1 ile 1 arasında olduğu görülmüștür. E-öğrenmeye yönelik motivasyon alt boyutunda basıklık değerinin -1'i göz ardı edilecek kadar çok az aştığı görülmüştür. Bu değerler Q-Q plot - normallik eğrisi çizilmiş histogram yöntemlerinden elde edilen sonuçları destekler şekilde olduğundan verilerin genel olarak normal dağılıma sahip olduğu söylenebilir.

\section{UEKT ve EÖHB düzeylerinin bağımsız değişkenlere göre incelenmesi}

Uzaktan eğitime karşı tutum (UEKT) ölçeğinden ve alt boyutlarıyla birlikte e-öğrenmeye hazır bulunuşluk (EÖHB) ölçeğinden elde edilen puanların cinsiyet değişkenine göre farklılaşıp farklılaşmadığını belirlemek için yapılan $t$ testinin sonuçları Tablo 3'te sunulmuştur.

Tablo 3

Cinsiyet Değişkenine Göre UEKT ve EÖHB Ölçek Puan Ortalamaları

\begin{tabular}{llllllll}
\hline Ölçek & Cinsiyet & $n$ & $\bar{X}$ & $S s$ & $t$ & $p$ & Etki \\
\hline UEKT & Kadın & 258 & 52,87 & 15,03 & $-1,76$ & 0,08 & \\
& Erkek & 75 & 56,31 & 14,39 & & & \\
EÖHB & Kadın & 258 & 146,72 & 39,56 & $-1,24$ & 0,22 & \\
\multirow{2}{*}{ Bilgisayar Öz-Yeterliği } & Erkek & 75 & 153,07 & 37,29 & & & \\
& Kadın & 258 & 18,94 & 7,57 & $-3,50$ & $0,00 *$ & \\
İnternet Öz-Yeterliği & Erkek & 75 & 22,43 & 7,68 & & & \\
& Kadın & 258 & 21,56 & 6,01 & $-1,59$ & 0,11 & \\
Çevrimiçi İletişim Öz-Yeterliği & Erkek & 75 & 22,79 & 5,32 & & & 0.46 \\
& Kadın & 258 & 22,11 & 7,91 & $-1,46$ & 0,15 & \\
Kendi Kendine Öğrenme & Erkek & 75 & 23,63 & 7,93 & & & \\
& Kadın & 258 & 40,72 & 10,06 & 1,02 & 0,31 & \\
Öğrenen Kontrolü & Erkek & 75 & 39,40 & 9,54 & & & \\
\multirow{2}{*}{ E-Öğrenmeye Yönelik Motivasyon } & Kadın & 258 & 20,62 & 5,77 & 1,30 & 0,20 & \\
& Erkek & 75 & 19,65 & 5,50 & & & \\
& Kadın & 258 & 22,76 & 12,14 & $-1,53$ & 0,13 & \\
\hline
\end{tabular}

Tablo 3'teki bağımsız örneklemler $\mathrm{t}$ testi sonuçları incelendiğinde UEKT ve EÖHB ölçeklerinden elde edilen puanların cinsiyete göre farklılaşmadığı bulunmuştur. EÖHB'nin alt ölçeklerine bakıldığında ise bilgisayar öz-yeterliği boyutu hariç diğer tüm boyutlarda kız ve erkek öğrenciler arasında farklılık olmadığı görülmektedir. Bilgisayar öz-yeterliği alt ölçeğinde erkek öğrencilerin öz-yeterlik algısı kadın öğrencilerden daha yüksektir $(p<0,01)$. Gruplar arasındaki bu farkın etki büyüklüğünün ise ortaya yakın zayıf düzeyde olduğu bulunmuştur.

Yaş değişkenine göre UEKT ölçeğinden ve alt boyutlarıly birlikte EÖHB ölçeğinden elde edilen puanların farkına ilişkin Kruskal-Wallis testi sonuçları Tablo 4'te sunulmuştur.

Tablo 4

Yaş Değişkenine Göre UEKT ve EÖHB Kruskal Wallis Testi

\begin{tabular}{lllll}
\hline Ölçek & Kruskal-Wallis H & sd & $p$ & Cohen $d$ \\
\hline UEKT & 0,1 & 3 & 0,99 & \\
EÖHB & 7,07 & 3 & 0,07 & \\
Bilgisayar Öz-Yeterliği & 6,79 & 3 & 0,08 & \\
İnternet Öz-Yeterliği & 5,96 & 3 & 0,11 & 0,26 \\
Çevrimiçi İletişim Öz-Yeterliği & 8,32 & 3 & $0,04^{*}$ & 0 \\
Kendi Kendine Öğrenme & 4,16 & 3 & 0,25 & \\
Öğrenen Kontrolü & 4,38 & 3 & 0,22 & \\
E-Öğgrenmeye Yönelik Motivasyon & 4,06 & 3 & 0,26 & \\
\hline
\end{tabular}


Tablo 4'teki Kruskal Wallis testi sonuçlanı incelendiğinde yaş değişkenine göre EÖHB ölçeğinin çevrimiçi iletişim öz-yeterliği alt ölçeği sıralamalarında fark bulunurken $(p<0,05)$, diğer ölçeklerde fark bulunmamıştır. Tespit edilen farkın etki büyüklüğü incelendiğinde ise düşük düzeyde olduğu görülmektedir. Görülen farkın kaynağını incelemek adına yapılan Mann-Whitney U testlerinde 25 ve üzeri yaş grubunun 19-21 ve 22-24 yaş gruplarına göre daha yüksek çevrimiçi iletişim öz-yeterliği algısına sahip olduğu görülmüş̧ür.

UEKT ölçeğinden ve alt boyutlarıyla birlikte EÖHB ölçeğinden elde edilen puanların sınıf değişkenine göre farklı olup olmadığını belirlemek için yapılan ANOVA testi sonuçları Tablo 5'te verilmiştir.

Tablo 5

Sinıf Değişkenine Göre ANOVA Sonuçları

\begin{tabular}{|c|c|c|c|c|c|c|c|}
\hline Ölçek & $\begin{array}{l}\text { Varyans } \\
\text { Kaynağ1 }\end{array}$ & $\begin{array}{l}\text { Kareler } \\
\text { Toplamı }\end{array}$ & $\mathrm{Sd}$ & $F$ & $p$ & $\begin{array}{l}\text { Kismi } \\
\eta^{2}\end{array}$ & Fark \\
\hline \multirow[t]{2}{*}{ UETK } & G. Aras1 & 2924,87 & 3 & 4,51 & $0,00 * *$ & 0,05 & $2 . \sin 1 f>3 . \sin 1 f^{*} *$ \\
\hline & G. içi & 71145,60 & 329 & & & & \\
\hline \multirow[t]{2}{*}{ EÖHB } & G. Aras1 & 16836,22 & 3 & 3,76 & $0,01 *$ & 0,01 & 4. $\sin 1 f>3 . \sin 1 f *$ \\
\hline & G. içi & 490600,28 & 329 & & & & \\
\hline \multirow[t]{2}{*}{ Bilgisayar Öz-Yeterliği } & G. Aras1 & 450,62 & 3 & 2,56 & 0,06 & & \\
\hline & G. içi & 19325,97 & 329 & & & & \\
\hline \multirow[t]{2}{*}{ İnternet Öz-Yeterliği } & G. Aras1 & 285,40 & 3 & 2,80 & $0,04 *$ & 0,04 & $1 . \sin 1 f>3 . \sin 1 f *$ \\
\hline & G. içi & 11187,84 & 329 & & & & \\
\hline Çevrimiçi İletişim & G. Aras1 & 611,92 & 3 & 3,31 & $0,02 *$ & 0,05 & $1 . \sin 1 f>3 . \sin 1 f *$ \\
\hline Öz-Yeterliği & G. içi & 20270,61 & 329 & & & & $4 . \sin 1 f>3 . \sin 1 f *$ \\
\hline Kendi Kendine & G. Aras1 & 463,11 & 3 & 1,57 & 0,20 & & \\
\hline Öğrenme & G. içi & 32356,34 & 329 & & & & \\
\hline \multirow[t]{2}{*}{ Öğrenen Kontrolü } & G. Aras1 & 103,07 & 3 & 1,05 & 0,37 & & \\
\hline & G. içi & 10743,20 & 329 & & & & \\
\hline E-Öğrenmeye Yönelik & G. Aras1 & 1995,82 & 3 & 4,72 & $0,00 * *$ & 0,01 & 4. $\sin 1 f>1 . \sin 1 f *$ \\
\hline Motivasyon & G. içi & 46382,55 & 329 & & & & 4. $\sin 1 f>3 . \sin 1 f * *$ \\
\hline
\end{tabular}

${ }^{*} p<0,05,{ }^{* *} p<0,01$.

Tablo 5 incelendiğinde UETK $[F(3,329)=4,51, p=0,00]$ ve EÖHB $[F(3,329)=3,76, p=0,01]$ ölçeklerinden elde edilen puanların sınıf düzeyine göre farklılaştığ 1 görülmektedir. EÖHB'nin internet öz-yeterliği $[F(3,329)=2,80, \mathrm{p}=0,04]$, çevrimiçi iletişim öz-yeterliği $[F(3,329)=3,31$, $p=0,02]$ ve e-öğrenmeye yönelik motivasyon $[F(3,329)=4,72, p=0,01]$ alt ölçeklerinden elde edilen puanların da sınıf düzeyine göre farklılaştığ 1 görülmektedir. İstatistiksel olarak anlamlı olan bu farklılara ait etki büyüklükleri kısmi $\eta^{2}$ ile incelendiğinde ise tüm etkilerin 0,01 ile 0,05 arasında olması bu etkilerin küçük boyutta olduğunu göstermektedir.

Tespit edilen farklılıkların hangi sınıflar arasında olduğuna ilişkin Tukey ikili karşılaştırmalar testi sonuçlarına bakıldığında 3. sınıf öğrencilerinin farklılık görülen tüm ölçek puanlarında birinci ve ikinci sınıf düzeyinden anlamlı olarak daha düşük olduğu görülmektedir. UETK'de 2. sınıf, EÖHB genelinde 4. sınıf, internet öz-yeterliğinde 1. sınıf, çevrimiçi iletişim öz-yeterliğinde 1. ve 4. sınıf, e-öğrenmeye yönelik motivasyonda ise 4. sınıf puanlarının 3. sinıf puanlarından yüksek olduğu görülmüştür. Görülen diğer farklılıkta ise e-öğrenmeye yönelik motivasyonda 4. sınıf puanlarının 1. sınıf puanlarından da yüksek olduğu bulunmuştur.

UEKT ölçeğinden ve alt boyutlarıyla birlikte EÖHB ölçeğinden elde edilen puanların öğrenim görülen bölüm değişkenine göre farkına ilişkin Kruskal-Wallis testi sonuçları Tablo 6'da sunulmuştur. 
Tablo 6

Bölüm Değişkenine Göre UEKT ve EÖHB Kruskal Wallis Testi

\begin{tabular}{lllll}
\hline Ölçek & Kruskal-Wallis H & sd & $p$ & Cohen $d$ \\
\hline UEKT & 14,47 & 6 & $0,03^{*}$ & 0,33 \\
EÖHB & 3,98 & 6 & & 0,68 \\
Bilgisayar Öz-Yeterliği & 14,65 & 6 & $0,02^{*}$ & 0,33 \\
İnternet Öz-Yeterliği & 14,40 & 6 & $0,03^{*}$ & 0,33 \\
Çevrimiçi İletişim Öz-Yeterliği & 15,25 & 6 & $0,02^{*}$ & 0,34 \\
Kendi Kendine Ögrenme & 6,52 & 6 & & 0,37 \\
Öğrenen Kontrolü & 7,25 & 6 & & 0,30 \\
E-Öğrenmeye Yönelik Motivasyon & 3,42 & 6 & & 0,76 \\
\hline
\end{tabular}

$* p<0,05$.

Tablo 6'daki Kruskal Wallis testi sonuçları incelendiğinde bölüm değişkenine göre UEKT ölçeği sıralamalarında fark bulunurken $(p<0,05)$ EÖHB ölçeği genelinde fark bulunamamıştır. EÖHB ölçeğinin bilgisayar öz-yeterliği, internet öz-yeterliği ve çevrimiçi iletişim öz-yeterliği alt boyutlarında da bölüm değişkenine göre fark bulunurken $(p<0,05)$, diğer üç alt boyut için fark gözlenmemiştir. Tespit edilen farkların etki büyüklükleri incelendiğinde tamamının düşük düzeyde olduğu görülmektedir.

Bölüm değişkenine göre istatistiksel olarak anlamlı fark bulunan ölçekler için farkın hangi bölümler arasında olduğunu belirlemek için Mann-Whitney U testi yapılmıştır. Buna göre UEKT ölçeğinde anlamlı farkın Türkçe öğretmenliği bölümü ile İlköğretim Matematik, Sınıf ve PDR öğretmenliği bölümleri arasında Türkçe bölümü aleyhine olduğu belirlenmiştir. Yani Türkçe bölümü öğrencilerinin uzaktan eğitime karşı tutumları anlamlı düzeyde daha düşük seviyededir. Benzer şekilde Fen Bilgisi öğretmenliği bölümü ile İlköğretim Matematik ve Sınıf öğretmenliği bölümleri arasında anlamlı farklılık bulunmuş̧tur. Buna göre Fen Bilgisi bölümü öğrencilerinin uzaktan eğitim tutumları İlköğretim Matematik ve Sınıf öğretmenliği bölümü öğrencilerinden daha düşüktür.

EÖHB ölçeğinde anlamlı fark görülen alt ölçeklere bakıldığında bilgisayar öz-yeterliği alt boyutunda İngilizce öğretmenliği bölümü öğrencilerinin diğer tüm bölümlerden, Sosyal Bilgiler öğretmenliği bölümü öğrencilerinin ise İlköğretim Matematik öğretmenliği bölümü öğrencilerinden anlamlı düzeyde daha yüksek ortalamaya sahip olduğu görülmüştür. İnternet özyeterliği alt boyutuna bakıldığında İngilizce öğretmenliği bölümü öğrencileri Sosyal Bilgiler öğretmenliği bölümü hariç diğer bölüm öğrencilerinden daha yüksek ortalamaya sahiptir, Sosyal Bilgiler öğretmenliği ve PDR bölümü öğrencileri ise Matematik öğretmenliği bölümü öğrencilerinden daha yüksek ortalamaya sahiptir. Çevrimiçi iletişim öz-yeterliği alt boyutunda ise İngilizce öğretmenliği bölümü diğer tüm bölümlerden, PDR bölümü öğrencilerinin ise Matematik öğretmenliği bölümü öğrencilerinden anlamlı bir şekilde daha yüksek ortalamaya sahip olduğu görülmüş̧ür.

Uzaktan eğitime karşı tutum (UEKT) ölçeğinden ve alt boyutlarıyla birlikte e-öğrenmeye hazır bulunuşluk (EÖHB) ölçeğinden elde edilen puanların "Size ait dizüstü ve/veya masaüstü bilgisayarınız var mı?" sorusu ile oluşturulan bilgisayar değişkenine göre farkına ilişkin t testi sonuçları Tablo 7'de sunulmuştur.

Tablo 7'deki bağımsız örneklemler t testi sonuçları incelendiğinde hem UEKT ölçeğinden hem EÖHB ölçeklerinden elde edilen puanların bilgisayara sahip olma durumuna göre farklılaştığ 1 bulunmuştur ( $p<0,01)$. UETK' da görülen farkın etki büyüklüğü düşük düzeyde iken EÖHB için orta düzey etki bulunmuştur. EÖHB'nin alt ölçeklerine bakıldığında da tüm alt boyutlarda bilgisayara sahip olma durumuna göre puanların farklılaştığı görülmüştür. Alt ölçeklerdeki farkın etki büyüklükleri kendi kendine ögrenme ve öğrenen kontrolü alt boyutları için düşük düzeyde 
iken diğer alt boyutlar için orta düzeyde olduğu bulunmuştur. Tüm ölçeklerde bilgisayara sahip olanların daha yüksek puan ortalamasına sahip olduğu görülmüsstür.

Tablo 7

Bilgisayar Değişkenine Göre UEKT ve EÖHB Ölçek Puan Ortalamaları

\begin{tabular}{|c|c|c|c|c|c|c|c|}
\hline Ölçek & Bilgisayar & $n$ & $\bar{X}$ & Ss & $t$ & $p$ & Cohen $d$ \\
\hline \multirow[t]{2}{*}{ UEKT } & Yok & 164 & 50,20 & 14,66 & \multirow{2}{*}{$-4,25$} & \multirow{2}{*}{$0,00 * *$} & \multirow[t]{2}{*}{0,47} \\
\hline & Var & 169 & 56,98 & 14,49 & & & \\
\hline \multirow[t]{2}{*}{ EÖHB } & Yok & 164 & 135,75 & 36,93 & \multirow{2}{*}{$-5,60$} & \multirow{2}{*}{$0,00 * *$} & \multirow[t]{2}{*}{0,66} \\
\hline & Var & 169 & 160,18 & 37,43 & & & \\
\hline \multirow[t]{2}{*}{ Bilgisayar Öz-Yeterliği } & Yok & 164 & 16,98 & 6,91 & \multirow{2}{*}{$-6,83$} & \multirow{2}{*}{$0,00 * *$} & \multirow[t]{2}{*}{, 075} \\
\hline & Var & 169 & 22,39 & 7,54 & & & \\
\hline \multirow[t]{2}{*}{ İnternet Öz-Yeterliği } & Yok & 164 & 20,16 & 5,82 & \multirow{2}{*}{$-5,34$} & \multirow{2}{*}{$0,00 * *$} & \multirow[t]{2}{*}{0,59} \\
\hline & Var & 169 & 23,47 & 5,48 & & & \\
\hline \multirow[t]{2}{*}{ Çevrimiçi İletişim Öz-Yeterliği } & Yok & 164 & 20,47 & 7,79 & \multirow{2}{*}{$-4,63$} & \multirow{2}{*}{$0,00 * *$} & \multirow[t]{2}{*}{0,51} \\
\hline & Var & 169 & 24,38 & 7,61 & & & \\
\hline \multirow[t]{2}{*}{ Kendi Kendine Öğrenme } & Yok & 164 & 39,04 & 9,93 & \multirow{2}{*}{$-2,53$} & \multirow{2}{*}{$0,01 *$} & \multirow[t]{2}{*}{0,28} \\
\hline & Var & 169 & 41,78 & 9,80 & & & \\
\hline \multirow[t]{2}{*}{ Öğrenen Kontrolü } & Yok & 164 & 19,47 & 5,72 & \multirow{2}{*}{$-2,98$} & \multirow{2}{*}{$0,00 * *$} & \multirow[t]{2}{*}{0,33} \\
\hline & Var & 169 & 21,31 & 5,58 & & & \\
\hline \multirow[t]{2}{*}{ E-Öğrenmeye Yönelik Motivasyon } & Yok & 164 & 19,64 & 11,13 & \multirow{2}{*}{$-5,71$} & \multirow{2}{*}{$0,00 * *$} & \multirow[t]{2}{*}{0,63} \\
\hline & Var & 169 & 26,86 & 11,91 & & & \\
\hline
\end{tabular}

$* p<0,05, * * p<0,01$

UEKT ölçeğinden ve alt boyutlarıyla birlikte EÖHB ölçeğinden elde edilen puanların "Kaldığınız yerde (ev, yurt) internet bağlantısı var mı?" sorusu ile oluşturulan internet değişkenine göre farkına iliş̧kin $t$ testi sonuçları Tablo 8 'de sunulmuştur.

Tablo 8

Internet Değişkenine Göre UEKT ve EÖHB Ölçek Puan Ortalamaları

\begin{tabular}{llllllll}
\hline Ölçek & İnternet & $n$ & $\bar{X}$ & Ss & $t$ & $p$ & Cohen $d$ \\
\hline UEKT & Yok & 136 & 49,81 & 13,79 & $-3,98$ & $0,00 *$ & 0,45 \\
& Var & 197 & 56,29 & 15,15 & & & \\
EÖHB & Yok & 136 & 132,79 & 37,95 & $-6,29$ & $0,00 *$ & 0,70 \\
& Var & 197 & 158,75 & 36,34 & $-6,29$ & & \\
Bilgisayar Öz-Yeterliği & Yok & 136 & 16,99 & 7,44 & $-5,61$ & $0,00 *$ & 0,62 \\
& Var & 197 & 21,61 & 7,35 & & & \\
İnternet Öz-Yeterliği & Yok & 136 & 19,76 & 6,11 & $-5,44$ & $0,00 *$ & 0,62 \\
& Var & 197 & 23,27 & 5,27 & & & \\
Çevrimiçi İletişim Öz-Yeterliği & Yok & 136 & 19,96 & 8,05 & $-4,93$ & $0,00 *$ & 0,54 \\
& Var & 197 & 24,17 & 7,40 & & & \\
Kendi Kendine Öğrenme & Yok & 136 & 38,21 & 10,38 & $-3,43$ & $0,00 *$ & 0,38 \\
& Var & 197 & 41,95 & 9,36 & & & \\
Öğrenen Kontrolü & Yok & 136 & 18,46 & 5,88 & $-5,27$ & $0,00 *$ & 0,60 \\
E-Öğrenmeye Yönelik Motivasyon & Var & 197 & 21,75 & 5,21 & & & \\
& Yok & 136 & 19,40 & 10,88 & $-5,08$ & $0,00 *$ & 0,57 \\
\hline
\end{tabular}

${ }^{*} p<0,05, * * p<0,01$.

Tablo 8'deki bağımsız örneklemler t testi sonuçları incelendiğinde hem UEKT ölçeğinden hem EÖHB ölçeklerinden elde edilen puanların internet bağlantısına sahip olma durumuna göre farklılaştığı bulunmuş̧tur ( $\mathrm{p}<0,01)$. UEKT'de görülen farkın etki büyüklüğü düşük düzeyde iken EÖHB için orta düzey etki bulunmuştur. EÖHB'nin alt ölçeklerine bakıldığında da tüm alt boyutlarda puanların internet bağlantısına sahip olma durumuna göre alt ölçek puanlarının 
farklılaştığ1 görülmüştür. Alt ölçeklerdeki farkın etki büyüklükleri sadece kendi kendine öğrenme alt boyutu için düşük düzeyde iken diğer alt boyutlar için orta düzeyde olduğu bulunmuştur. Tüm ölçeklerde kaldığ 1 yerde internet bağlantısına sahip olanların daha yüksek puan ortalamasına sahip olduğu görülmüştür.

UEKT ölçeğinden ve alt boyutlarıyla birlikte EÖHB ölçeğinden elde edilen puanların "İnternet bağlantısı olan akıllı telefonunuz var mı?" sorusu ile oluşturulan akıllı telefon değişkenine göre farkına ilişkin Mann-Whitney U testi sonuçları Tablo 9'da sunulmuştur.

Tablo 9'daki Mann-Whitney U testi sonuçları incelendiğinde ak1llı telefona sahip olma durumuna göre UEKT ölçeğinden elde edilen puanların farklılaşmadığı görülürken, EÖHB ölçeğinden elde edilen puanların farklılaştığı bulunmuştur $(\mathrm{p}<0,05)$. Bu farka ait etki büyüklüğü düşük düzeyde bulunmuştur. EÖHB'nin alt ölçeklerine bakıldığında ise sadece öğrenen kontrolü alt boyutunda akı1lı telefona sahip olma durumuna göre alt ölçek puanlarının farklılaştığı görülmüştür. Farkın etki büyüklügünün ise düşük düzeyde olduğu bulunmuştur. Bu bulguya göre akıllı telefona sahip olan öğrencilerin EÖHB ölçek genelinde ve öğrenen kontrolü alt ölçeğinde puan ortalamaları akıllı telefona sahip olmayan öğrencilere göre daha yüksektir.

Tablo 9

Akıllı Telefon Değişkenine Göre UEKT ve EÖHB Ölçek Puan Ortalamaları

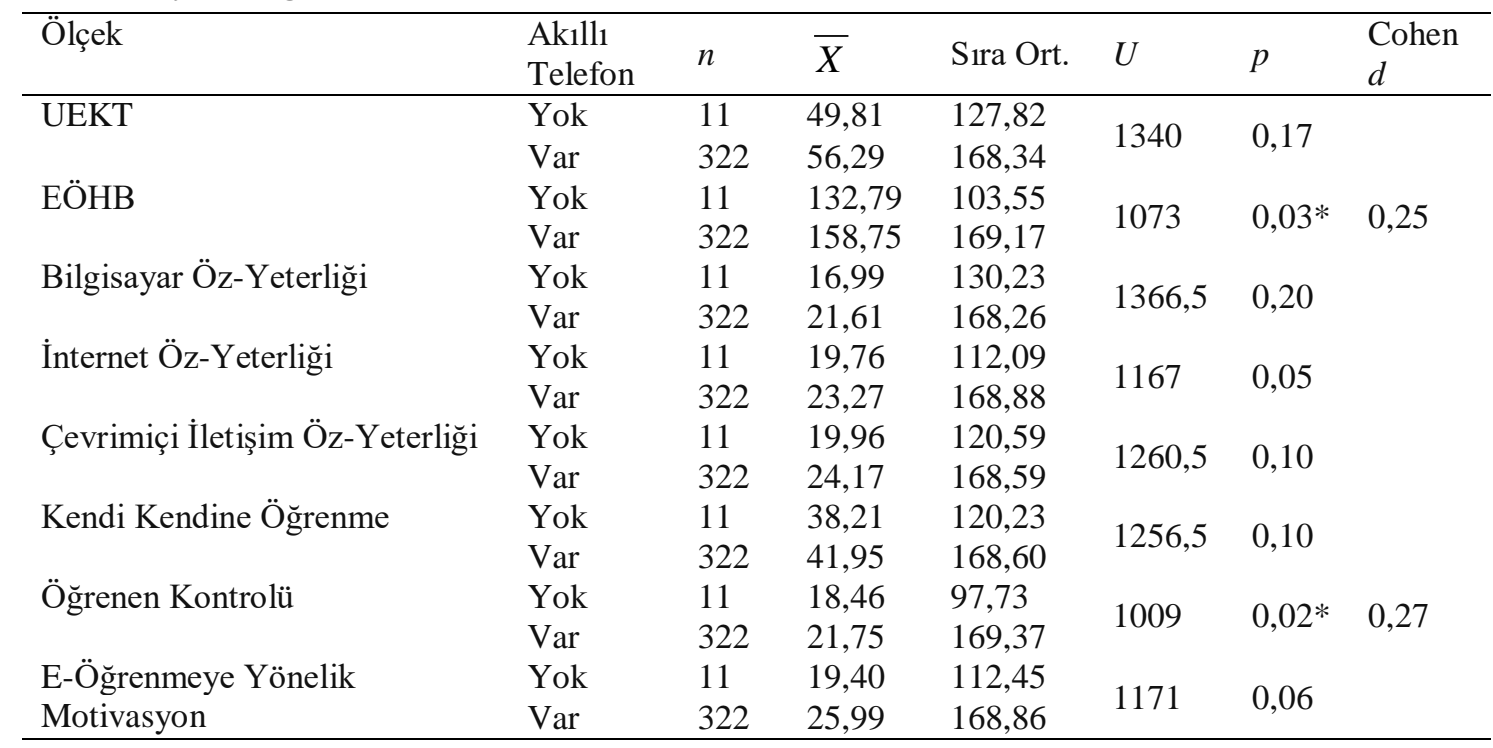

$* \mathrm{p}<0,05$.

UEKT ölçeğinden ve alt boyutlarıyla birlikte EÖHB ölçeğinden elde edilen puanların "Daha önce uzaktan eğitim platfomlarını (Uzem, Google Classroom, Beyazpano vb.) kullandınız mı?" sorusu ile oluşturulan deneyim değişkenine göre farkına ilişkin t testi sonuçları Tablo 10'da sunulmuştur.

Tablo 10'daki bağımsız örneklemler t testi sonuçları incelendiğinde, UEKT ölçeğinden elde edilen puanların deneyim sahibi olma durumuna göre farklılaşmadığı görülürken, EÖHB ölçeğinden elde edilen puanların farklılaştı̆̆ bulunmuştur $(p<0,01)$. Farka ait etki büyüklüğünün ise düşük düzeyde olduğu görülmüştür. Buna göre daha önceden uzaktan eğitim deneyimi olan öğrencilerin EÖHB ölçeğinin genelinde puanları daha yüksektir. EÖHB'nin alt ölçeklerine bakıldığında ise kendi kendine öğrenme ve öğrenen kontrolü alt ölçek puanlarında deneyime sahip olma durumuna göre farklılaşma görülmezken diğer alt ölçek puanlarında deneyime sahip olan öğrencilerin puanlarının daha yüksek olduğu görülmektedir. İstatistiksel olarak tespit edilen tüm farkların etki büyüklüklerinin düşük düzeyde olduğu görülmüştür. 
Tablo 10

Deneyim Değişkenine Göre UEKT ve EÖHB Ölçek Puan Ortalamaları

\begin{tabular}{llllllll}
\hline Değişken & Grup & $n$ & $\bar{X}$ & Ss & $t$ & $p$ & Cohen $d$ \\
\hline UEKT & Yok & 167 & 52,34 & 15,00 & $-1,61$ & 0,11 & \\
EÖHB & Var & 166 & 54,96 & 14,81 & & & \\
& Yok & 167 & 141,54 & 40,24 & $-3,14$ & $0,00^{* *}$ & 0,34 \\
Bilgisayar Öz-Yeterliği & Var & 166 & 154,80 & 36,84 & & & \\
& Yok & 167 & 18,25 & 7,38 & $-3,55$ & $0,00^{* *}$ & 0,39 \\
İnternet Öz-Yeterliği & Var & 166 & 21,20 & 7,79 & & & \\
& Yok & 167 & 20,62 & 6,23 & $-3,88$ & $0,00^{* *}$ & 0,43 \\
Çevrimiçi İletişşm Öz-Yeterliği & Var & 166 & 23,07 & 5,24 & & & \\
\multirow{2}{*}{ Kendi Kendine Öğrenme } & Yok & 167 & 21,13 & 7,96 & $-3,10$ & $0,00^{* *}$ & 0,34 \\
& Var & 166 & 23,79 & 7,69 & & & \\
Öğrenen Kontrolü & Yok & 167 & 39,51 & 10,73 & $-1,70$ & 0,09 & \\
& Var & 166 & 41,35 & 9,02 & & & \\
E-Öğrenmeye Yönelik Motivasyon & Yok & 167 & 20,12 & 5,95 &,- 91 & 0,36 & \\
& Var & 166 & 20,69 & 5,48 & & & \\
& Yok & 167 & 21,92 & 12,35 & $-2,11$ & $0,04 *$ & 0,23 \\
& Var & 166 & 24,70 & 11,65 & & & \\
\hline
\end{tabular}

$* p<0,05, * * p<0,01$.

\section{UEKT ve EÖHB düzeyleri arasındaki ilișki}

UEKT ölçeği ve alt boyutlarıyla birlikte EÖHB ölçeği arasındaki ilişkiyi incelemek için gerçekleştirilen Pearson korelasyon sonuçları Tablo 11'de sunulmuştur.

Tablo 11

Ölçekler Arasındaki Korelasyonlar

\begin{tabular}{lccccccc}
\hline & UETK & 1 & 2 & 3 & 4 & 5 & 6 \\
\hline 1. EÖHB & 0,52 & - & & & & & \\
2. Bilgisayar Öz-Yeterliği & 0,30 & 0,79 & - & & & & \\
3. İnternet Öz-Yeterliği & 0,27 & 0,79 & 0,76 & - & & & \\
4. Çevrimiçi İletişim Ö̈z-Yeterliği & 0,33 & 0,86 & 0,73 & 0,77 & - & & \\
5. Kendi Kendine Öğrenme & 0,30 & 0,81 & 0,48 & 0,53 & 0,61 & - & \\
6. Öğrenen Kontrolü & 0,30 & 0,78 & 0,48 & 0,52 & 0,57 & 0,80 & - \\
7. E-Öğrenmeye Yönelik Motivasyon & 0,74 & 0,74 & 0,45 & 0,41 & 0,50 & 0,46 & 0,47 \\
\hline
\end{tabular}

Tablo 11'de verilen tüm korelasyon katsayıları $p<0,01$ düzeyinde anlamlıdır. Ana ölçekler olan UEKT ile EÖHB arasında 0,52'lik korelasyon katsayıs1, bu değişkenlerin orta düzeyde pozitif ilişkili olduğunu göstermektedir. UETK ile EÖHB ölçeğinin alt boyutları arasındaki ilişkiler incelendiğinde e-öğrenmeye yönelik motivasyon ile yüksek, diğerleri ile düşük seviyede ilişkili olduğu bulunmuştur. EÖHB ölçeğinin alt boyutlarının kendi aralarındaki ilişkiler incelendiğinde, öz-yeterlikleri ölçen üç alt boyutun kendi aralarındaki ilişkiler ve kendi kendine öğrenme ve öğrenen kontrolü alt ölçekleri arasındaki ilişki yüksek iken diğer ilişki düzeylerinin orta seviyelerde olduğu görülmüştür.

\section{Tartışma, Sonuç ve Öneriler}

$\mathrm{Bu}$ araştırmada eğitim fakültesi öğrencilerinin uzaktan eğitime yönelik tutum ve e-öğrenmeye hazır bulunuşluk düzeylerinin belirlenmesi ve bunların birbirleri ile ve çeşitli değişkenlerle (yaş, cinsiyet, bölüm, bilgisayar, akıllı telefon, internet, deneyim) ilişkisinin incelenmesi amaçlanmıştır. Öncelikli olarak araştırmanın birinci alt problemi doğrultusunda öğrencilerin uzaktan eğitime yönelik tutum ve e-öğrenmeye hazır bulunuşluk düzeyleri tespit edilmiştir. Elde edilen bulgulara göre öğrencilerin uzaktan eğitim tutumları ortaya yakın düşük düzeyde, eöğrenmeye hazır bulunuşlukları ise yükseğe yakın orta düzeydedir. Bu sonuçları doğrulayan bir 
çalışmada Yağcı, Alsancak-Sırakaya ve Özüdoğru (2015), eğitim fakültesinde bilgisayar eğitimi ve teknoloji öğretimi bölümünde öğrenim gören öğretmen adaylarının web-tabanlı öğrenmeye karşı tutumlarının orta seviyenin hemen altında, e-öğrenmeye hazır bulunuşluklarının ise orta seviyenin hemen üstünde olduğu sonucuna ulaşmışlardır. Akgün (2015)'ün uzaktan eğitime kayıtll öğrencilerle gerçekleştirdiği benzer bir çalışmada da bu yönde bulgular elde edilmiştir. Buna göre öğrencilerin web tabanlı öğretim tutumlarının olumluya yakın kararsız seviyede olduğu, çevrimiçi teknolojilere yönelik öz-yeterlik algılarının ise ortalamanın üstünde olduğu belirlenmiştir. Yine alan yazında yer alan birçok çalışmada, öğrencilerin uzaktan eğitim tutumlarının kararsız seviyeye yakın veya düşük (Ateş ve Altun, 2008; Barış, 2015; Haznedar, 2012; Yıldız, 2016; Öztaş ve Kılıç, 2017; Yenilmez, Turgut ve Balbağ, 2017; Kışla, 2005) ve eöğrenmeye hazır bulunuşluklarının orta düzey veya yüksek (Çakır ve Horzum, 2015; Hung, Chou, ChenveOwn, 2010; Kabataş, 2019; Y1lmaz, Sezer ve Yurdugül, 2019; Yurdugül ve Demir, 2017) olduğu ortaya konmuştur. Bu çalışmanın dikkat çekici sonucu, öğrencilerin e-öğrenmeye hazır bulunuşluklarının, tutumlarına göre daha kabul edilebilir düzeyde olduğudur. Öğrencilerin çoğunluğunun daha önceden uzaktan eğitim deneyiminin olmayışı ve Covid-19 salgınının getirdiği belirsizliklerle birlikte uzaktan eğitim alma durumunda kalmaları, uzaktan eğitim tutumlarının orta seviyeye yakın olmakla beraber düşük çıkmasının nedeni olarak gösterilebilir. Öğrencilerin e-öğrenme hazır bulunuşluklarının daha yüksek çıkmasında ise bilgi ve iletişim teknolojilerinin hayatımızın her alanında kullanımının artmış olmasının (Aktaş ve Çaycı, 2013) bir sonucu olarak birçok öğrencinin bilgi ve iletişim teknolojileri becerilerine sahip olması (Haznedar, 2012) etkili olmuştur denebilir.

Çalı̧̧mada ayrıca öğrencilerin e-öğrenmeye hazır bulunuşluk yapısının her bir alt boyutu için düzeyleri belirlenmiştir. Bu inceleme öğrencilerin e-öğrenmeye hazır bulunuşluğunun özellikle hangi boyutlarında daha güçlü hangi boyutlarında daha zayıf olduklarının bilinmesi bakımından önemlidir. Buna göre öğrencilerin internet öz yeterliği, öğrenen kontrolü ve kendi kendine öğrenme boyutlarında hazır bulunuşluklarının yüksek, çevrimiçi iletişım öz yeterliği ve bilgisayar öz yeterliği boyutlarında ise hazır bulunuşluklarının orta düzeyde olduğu ortaya çıkmıştır. Öğrencilerin hazır bulunuşluklarının düşük olduğu boyut ise e-öğrenmeye yönelik motivasyon boyutudur. Puan ortalamalarına göre öğrencilerin hazır bulunuşluklarının artırılması gereken boyutlar olarak özellikle bilgisayar öz yeterliği ve e-öğrenmeye yönelik motivasyon boyutları dikkat çekmektedir. Çalışmada duyuşsal özellikler kapsamında yer alan e-öğrenmeye yönelik motivasyon boyutu ile ilgili ulaşılan bu sonucun, öğrencilerin uzaktan eğitime karşı tutum düzeyleri ile örtüştügü görülmektedir. Bu çalışmada olduğu gibi Yılmaz, Sezer ve Yurdugül (2019) ile Yurdugül ve Demir'in (2017) çalışmalarında da üniversite öğrencilerinin e-öğrenmeye hazır bulunuşluğu açısından yeterliklerinin en yüksek olduğu boyutun internet öz yeterliği, en düşük olduğu boyutların ise bilgisayar öz-yeterliği ve e-öğrenmeye yönelik motivasyon boyutları olduğu görülmüştür. Yurdugül ve Demir (2017), mobil teknolojiler sayesinde öğrencilerin internete erişimlerinin kolaylaşmasının internet öz yeterliğindeki yüksek ortalamada etkili olabileceğini, öğrencilerin motivasyonlarının düşük olmasının ise istek ve ilgi gibi duyuşsal etkenler ile açıklanabileceğini belirtmiş̧lerdir. Yılmaz, Sezer ve Yurdugül (2019) çalışmalarında, öğrencilerin bilgisayar öz yeterliklerini artırmak için ihtiyaç duyulan eğitim desteğinin verilmesi gerektiğini, motivasyon seviyelerini artırmak için de yüz yüze derslerin çevrimiçi dersler ile karma öğrenme şeklinde yürütülerek öğrencilere anlamlı deneyim firsatı sunulmasının yararlı olabileceğini belirtmişlerdir.

Araştırmanın ikinci alt problemi doğrultusunda öğrencilerin uzaktan eğitime yönelik tutumları ve e-öğrenmeye hazır bulunuşlukları cinsiyet, yaş, bölüm, bilgisayar, internet, akıllı telefon ve deneyim değişkenleri açısından incelenmiştir. Elde edilen sonuçlara göre öğrencilerin uzaktan eğitime yönelik tutumları cinsiyet, yaş, akıllı telefon ve deneyim değişkenlerine göre farkl1lık göstermemektedir. Alan yazında bu çalışmada olduğu gibi cinsiyet değişkeninin öğrencilerin uzaktan eğitim tutumları üzerinde etkili olmadığını ortaya koyan çalışmalar bulunmaktadır (Ateş ve Altun, 2008; Akgün, 2015; Çiftçi, Güneş ve Üstündağ, 2010; Durmuş ve Bağc1, 2013; Kışla, 
2005; Yağc1, Alsancak-Sirakaya ve Özüdoğru, 2015; Yıldız, 2016). Bununla birlikte, alan yazında erkek öğrenciler lehine olmak üzere cinsiyet değişkeninin uzaktan eğitime yönelik tutum üzerinde etkili olduğunu gösteren çalışmalar da mevcuttur (Haznedar, 2012; Tekinarslan, 2008; Yenilmez, Turgut ve Balbağ, 2017). Bu çalışmada elde edilen uzaktan eğitim deneyiminin tutum üzerinde etkili olmadığ1 sonucunun aksine ilgili çalışmalarda çoğunlukla daha önceden uzaktan eğitim uygulamasına katılan veya ön bilgileri olan öğrencilerin uzaktan eğitimle ilgili daha olumlu tutuma sahip oldukları sonucuna ulaşılmıştır (Ateş ve Altun, 2008; Durmuş ve Bağc1, 2013; Kışla, 2005; Yenilmez, Turgut ve Balbağ, 2017). Yine akıllı telefon değişkeniyle ilgili olarak ulaşılan sonuçtan farklı olarak Barış'ın (2015) çalışmasında akıllı telefonu olan öğrencilerin olmayanlara göre uzaktan eğitim tutumlarının daha olumlu olduğu belirlenmiştir.

Uzaktan eğitime yönelik tutum üzerinde etkili olduğu belirlenen sınıf düzeyi, öğrenim görülen bölüm, bilgisayar ve internet değişkenleri ile ilgili olarak elde edilen bulgular ise şöyledir: $2 . \sin ı f$ öğrencileri 3.sınıf öğrencilerine göre uzaktan eğitime karşı daha olumlu tutuma sahiptirler. Türkçe öğretmenliği bölümü öğrencileri İlköğretim Matematik ve Sınıf öğretmenliği ile PDR bölümü öğrencilerine göre Fen Bilgisi öğretmenliği öğrencileri ise İlköğretim Matematik ve Sınıf öğretmenliği bölümü öğrencilerine göre daha olumsuz tutuma sahiptirler. Bilgisayarı olan öğrencilerin ve internet erişimi olan öğrencilerin uzaktan eğitim tutumları bilgisayar ve internet erişimi olmayan öğrencilere göre daha yüksektir. Bu çalışmada olduğu gibi alan yazında sınıf düzeyinin (Çiftçi, Güneş ve Üstündağ, 2010; Durmuş ve Bağc1, 2013; Durmuş ve Kaya, 2011; Haznedar, 2012; Yağc1, Alsancak-Sirakaya ve Özüdoğru, 2015), öğrenim görülen bölümün (Durmuş ve Bağc1, 2013; Gündüz, 2013; Kışla, 2005; Yenilmez, Turgut ve Balbağ, 2017), bilgisayara sahip olma durumunun (Ateş ve Altun, 2008; Barış, 2015; Chang ve Tung, 2008; Kabataş, 2019; Kışla, 2005) ve internet erişiminin (Barış, 2015; Demir, 2013; Durmuş ve Bağc1, 2013) tutum üzerinde etkili değişkenler olduğunu gösteren çalışmalar bulunmaktadır. Ancak bu çalışmalarda bilgisayar ve internet erişimi değişkeni hariç sınıf düzeyi ve bölüm değişkenleriyle ilgili olarak mevcut çalışmadan farklı sonuçlara ulaşıldığ 1 görülmektedir. Örneğin Yenilmez, Turgut ve Balbağ'ın (2017) çalışmasında ulaşılan, Fen Bilgisi öğretmeni adaylarının Sınıf öğretmeni adaylarına göre uzaktan eğitime yönelik tutumlarının daha olumlu olduğu sonucu ile Durmuş ve Bağcı'nın (2013) çalışmasında ulaşılan Bilgisayar ve Öğretim Teknolojileri öğretmenliği bölümü hariç diğer bölümler arasında farklılık olmadığı sonucu bu çalışma ile uyuşmamaktadır. Benzer şekilde çalışmada sınıf düzeyi değişkeni ile ilgili olarak elde edilen sonuçtan farklı olarak Ateş ve Altun'un (2008) çalışmasında öğrencilerin uzaktan eğitime yönelik tutumlarının, sınıflarına göre farklılık göstermediği görülmüştür. Yine bu çalışmada ulaşılan 2 . sınıf öğrencilerinin uzaktan eğitim tutumlarının 3. sınıf öğrencilerinden daha olumlu olduğu ve diğer sınıf düzeyleri arasında farklılık olmadığı sonucu, Haznedar (2012), Çiftçi, Güneş ve Üstündağ (2010) ve Durmuş ve Kaya'nın (2011) çalışmalarında üniversite öğrencilerinin sınıf düzeyleri arttıkça e-öğrenmeye yönelik tutumlarının da arttı̆̆ 1 sonucunu desteklememektedir. Bölüm değişkeni açısından düşünüldüğünde bölümlerin birbirinden temel farkının ilgili olunan yetenek (sözel, sayısal, dil) türü olmasına rağmen uzaktan eğitime karşı tutumda bu temel farklılığın etkin olmadığı görülmektedir. Benzer şekilde uzaktan eğitime yönelik tutumun, sınıf düzeylerine göre düzenli olarak farklılaşmadığı da görülmüştür. Alan yazından farklı bulunan bu sonuçların nedenleri nitel araştırma yöntemleri ile ortaya çıarılabilir.

Araştırmada öğrencilerin e-öğrenmeye hazır bulunuşluklarının cinsiyet, yaş ve bölüm değişkenlerine göre farklılaşmadığı bununla birlikte sınıf düzeyi, bilgisayar, internet, akıllı telefon ve deneyim değişkenlerinin öğrencilerin e-öğrenmeye hazır bulunuşluk düzeyleri üzerinde etkili olduğu belirlenmiştir. E-öğrenmeye hazır bulunuşluğu üzerinde değişkenlerin etkililiği ile ilgili ulaşılan bu sonuçlar e-öğrenmeye hazır bulunuşluk yapısının bazı alt boyutları bakımından ise farklılık gösterebilmektedir. Cinsiyet değişkeni E-Öğrenmeye Hazır Bulunuşluk ölçeği genelinde farklılık oluşturmamakla birlikte, EÖHB'nin alt boyutlarına bakıldığında ise sadece bilgisayar öz-yeterliği boyutunda etkili olduğu görülmüştür. Buna göre bilgisayar özyeterliği boyutunda erkek öğrencilerin öz-yeterlik algısı kadın öğrencilerden daha yüksektir. Alan 
yazında bu sonucu destekleyecek şekilde erkeklerin kadınlara kıyasla bilgisayar teknolojilerinde daha yeterli olduklarını gösteren çalışmalar mevcuttur (Alsancak-Sırakaya ve Yurdugül, 2016; Aypay, 2010; Çetin ve Güngör, 2014; Haznedar, 2012). Yılmaz, Sezer ve Yurdugül'ün (2019) çalışmasında ise gerek e-öğrenmeye hazır bulunuşluk yapısının genelinde gerekse de her bir alt boyutunda erkek öğrencilerin kadın öğrencilere göre daha yüksek yeterliğe sahip oldukları belirlenmiştir. Sakal'ın (2017) çalışmasında ise öğrencilerin bilgisayar öz-yeterliklerinin cinsiyet değişkenine göre farklılaşmadığı sadece çevrimiçi iletişim öz-yeterliği boyutunda erkek öğrenciler lehine farkl11ık bulunduğu belirlenmiştir. Yine bu çalışmadan farklı olarak Akgün'ün (2015) çalışmasında erkek öğrencilerin internet becerilerinin ve çevrimiçi iletişim özyeterliklerinin daha yüksek olduğu ortaya çıkmıştır.

Yaş değişkenine göre EÖHB genelinde farklılık bulunmamakla birlikte çevrimiçi iletişim özyeterliği alt boyutunda farklılık tespit edilmiştir. Buna göre 25 ve üzeri yaş grubunda yer alan öğrenciler, 19-21 ve 22-24 yaş grubundaki öğrencilere göre daha yüksek çevrimiçi iletişim özyeterliği inancına sahipler. Yine bölüm değiş̧enine göre EÖHB genelinde fark bulunmazken, bilgisayar öz yeterliği, internet öz yeterliği ve çevrimiçi iletişim öz yeterliği alt boyutlarında farklılık bulunmaktadır. Elde edilen bulgulara göre İngilizce öğretmenliği bölümü öğrencilerinin bilgisayar ve çevrimiçi iletişim öz yeterlikleri diğer tüm bölüm öğrencilerinden, internet öz yeterlikleri ise Sosyal Bilgiler öğretmenliği bölümü hariç diğer bölüm öğrencilerinden yüksektir. Sosyal Bilgiler öğretmenliği bölümü öğrencilerinin bilgisayar ve internet öz yeterlikleri İlköğretim Matematik öğretmenliği bölümü öğrencilerinden daha yüksektir. PDR bölümü öğrencilerinin internet ve çevrimiçi iletişim öz yeterlikleri İlköğretim Matematik öğretmenliği bölümü öğrencilerinden daha yüksektir. Bu bulgular birlikte değerlendirildiğinde İngilizce öğretmenliği bölümü öğrencilerinin hazır bulunuşluklarının diğer öğrencilere göre daha yeterli olduğu, e-öğrenmeye hazır bulunuşluklarının artırılması gereken bölümlerin başında ise ilköğretim matematik öğretmenliği bölümünün geldiği söylenebilir. Bu bulguya benzer olarak Yurdugül ve Demir'in(2017) öğretmen yetiştiren lisans programlarına göre öğrencilerin eöğrenmeye hazır bulunuşluklarını inceledikleri çalışmada, en yüksek hazır bulunuşluğa Alman Dili ve Öğretimi programında öğrenim gören öğrencilerin, en düşük hazır bulunuşluğa ise ilköğretim Matematik Öğretmenliği bölümü öğrencilerinin sahip olduğu belirtilmiştir. Bu sonuç çalışmada ortaya çıkan diğer bir dil öğretmenliği olan İngilizce Öğretmenliği öğrencilerinin bazı boyutlarda yüksek, İlköğretim Matematik Öğretmenliği öğrencilerinin ise bazı boyutlarda düşük hazır bulunuşluğa sahip olduğu sonucuyla örtüşmektedir.

Elde edilen bulgulara göre sınıf düzeyi değişkeni bakımından öğrencilerin genel EÖHB'leri yanı sıra internet öz-yeterliği, çevrimiçi iletişim öz-yeterliği ve e-öğrenmeye yönelik motivasyon boyutlarında hazır bulunuşlukları farklılaşmaktadır. Ortaya çıkan farklılıklar incelendiğinde 4.sınıf öğrencilerinin hazır bulunuşluklarının EÖHB ölçek genelinde ve çevrimiçi iletişim öz yeterliğinde 3.sinıf öğrencilerinden ve e-öğrenmeye yönelik motivasyonda ise 1 . ve 3 . sinıf öğrencilerinden daha yüksek olduğu görülmüştür. Bir diğer sonuca göre ise 1.sınıf öğrencilerinin internet öz yeterliği ve çevrimiçi iletişim öz yeterliği 3. sınıf öğrencilerinden anlamlı düzeyde daha yüksektir. Bu sonuçlar birlikte değerlendirildiğinde 4. sınıf öğrencilerinin e-öğrenmeye hazır bulunuşluklarının daha iyi durumda olduğu, 3. sınıf öğrencilerinin hazır bulunuşluklarının ise en düşük olduğu söylenebilir. Alan yazında yer alan benzer çalışmalarda (Alsancak-Sırakaya ve Yurdugül, 2016; Hung vd., 2010; Y1lmaz, Sezer ve Yurdugül, 2019; Yurdugül ve Demir, 2017) sınıf düzeyinin e-öğrenmeye hazır bulunuşluktaki etkililiği incelenirken, elde edilen bulguları daha anlamlı yordayabilmek adına sadece 1. ve 4. sınıf karşılaştırması yapıldığg görülmüsştür. Bu çalışmanın sonucuyla benzerlik taşıyan bir çalışmada Hung vd. (2010) 4. sınıf öğrencilerinin eöğrenmeye yönelik motivasyon öz-yeterliğinin, çevrimiçi iletişim öz-yeterliğinin ve öğrenen kontrolünün daha yüksek olduğunu belirtmiştir. Yurdugül ve Demir (2017) ile Y1lmaz, Sezer ve Yurdugül'ün (2019) çalışmalarının her ikisinde de 4. sınıftaki öğrencilerin EÖHB ölçek genelinde ve her bir alt boyutunda hazır bulunuşluklarının istatistiksel olarak yüksek olduğu belirlenmiştir. $\mathrm{Bu}$ durumun öğrencilerin ara sinıflarda teknoloji destekli dersler almalarından 
kaynaklanabileceğini belirtmişlerdir. Alsancak-Sırakaya ve Yurdugül'ün (2016) çalışmalarında ise farklı olarak sadece bilgisayar/internet özyeterliğinin sınıf düzeyine göre farklılaştı̆̆ 1 ve bu farklılığın 4. sınıf öğrencileri lehine olduğu açıklanmıştır. Bu sonucun, öğrencilerin öğrenim hayatlarında derslerinde sürekli bilgisayar ve interneti aktif kullanma durumunda kalmaları ile açıklanabileceğini belirtmiş̧lerdir. Alan yazına uygun şekilde daha fazla öğrenim hayatına sahip 4. sınıf öğrencilerinin e-öğrenmeye hazır bulunuşluklarının yüksek çıkmasının beklenen bir sonuç olduğu söylenebilir.

Araştırmada bilgisayara, internet erişimine, akıllı telefona ve uzaktan eğitim deneyimine sahip olan öğrencilerin, olmayan öğrencilere göre e-öğrenmeye hazır bulunuşluklarının daha yüksek olduğu sonucuna ulaşılmıştır. EÖHB' nin boyutları bakımından ise bilgisayarı ve internet erişimi olan öğrencilerin tüm boyutlarda, ak1llı telefonu olan öğrencilerin sadece öğrenen kontrolü boyutunda ve daha önceden uzaktan eğitim deneyimi olan öğrencilerin ise bilgisayar, internet ve çevrimiçi iletişim öz- yeterliği boyutlarında hazır bulunuşluklarının anlamlı düzeyde daha yükssek olduğu görülmüştür. Bu bulgulara paralel olarak, Yılmaz, Sezer ve Yurdugül'ün (2019) çalışmasında da kişisel bilgisayarı ve akıllı telefonu olan öğrencilerin, tüm boyutlarıyla birlikte eöğrenmeye hazır bulunuşluk durumlarının anlamlı derecede yüksek olduğu sonucu elde edilmiştir. Bu sonuçları destekler şekilde Haznedar'ın (2012) çalışmasında üniversite öğrencilerinin bilgisayar kullanma deneyimi ve internet kullanma sıklığ iletişim teknolojileri becerilerinin arttığı sonucuna ulaşılmıştır. Hazır bulunuşlukların kullanıma bağlık olarak değişebilecek bir özellik olması nedeniyle ilgili teknolojiye veya deneyime sahip öğrencilerin diğer öğrencilere göre e-öğrenmeye daha hazır olmaları da beklenen bir durum olarak değerlendirilebilir.

Araştırmanın üçüncü alt problemi ile ilgili olarak öğrencilerin uzaktan eğitim tutumları ile eöğrenmeye hazır bulunuşlukları arasındaki ilişki incelenmiştir. Sonuç olarak uzaktan eğitime yönelik tutum ile e-öğrenmeye hazır bulunuşluğun orta düzeyde ilişkili olduğu görülmüştür. Eöğrenmeye hazır bulunuşluk yapısının alt boyutları bakımından ise uzaktan eğitime karșı tutum ile motivasyon boyutu arasında beklenildiği gibi yüksek düzeyde, diğer boyutlar ile düşük düzeyde ilişki bulunmuştur. Uzaktan eğitime yönelik tutum ile e-öğrenmeye yönelik motivasyon aynı kaynaktan beslenen, birbirine yakın duyuşsal özellikler olması aralarında yüksek ilişki olduğu söylenebilir. Alan yazında uzaktan eğitim tutumu ile e-öğrenmeye hazır bulunuşluk arasındaki ilişkinin incelendiği çalışmaya rastlanmamakla birlikte benzer bir çalışmada Akgün (2015) öğrencilerin web tabanlı ögretime yönelik tutumları ile çevrim içi teknolojilere yönelik öz-yeterlik algıları arasında pozitif yönde fakat düşük düzeyde ilişki olduğunu belirlemiştir. Araştırmada ayrıca e-öğrenmeye hazır bulunuşluk yapısına ait boyutların kendi aralarındaki ilişkinin incelenmesi sonucunda, bilgisayar, internet ve çevrimiçi iletişim öz-yeterliğinin kendi aralarındaki ilişkinin ve yine kendi kendine öğrenme ve öğrenen kontrolü arasındaki ilişkinin yüksek düzeyde diğer ilişki türlerinin ise orta düzeyde olduğu sonucuna ulaşılmıştır. Bu sonuçlar, Yurdugül ve Demir (2017) ile Hung ve diğerlerinin (2010) çalışmalarından elde edilen sonuçlarla tutarl1l1k göstermektedir.

Araştırmadan ulaşılan sonuçlar doğrultusunda şu öneriler geliştirilmiştir:

1. Araştırmanın odağında yer alan üniversitenin ilgili birimleri ve uygulayıcılar tarafından bu sonuçların incelenmesi, öğrencilerle ilgili daha kapsamlı durum tespiti yapılması ve öğrencilere ihtiyaçları olan desteğin sağlanması gerekmektedir. Ancak bu sayede bundan sonraki süreçlerde öğrencilerin uzaktan eğitim uygulamalarından en etkili ve verimli şekilde yararlanabilmeleri mümkün hale gelebilecektir.

2. Öğretmen adaylarının geleceğin öğretim modeli olarak öne çıkan uzaktan eğitimi tanımaları ve uygulayabilmeleri için bazı yükseköğrenim derslerinde uzaktan eğitime ilişkin teorik ve uygulamalı çalışmalar yapılması sağlanmalıdır. $\mathrm{Bu}$ anlamda 
Yükseköğretim Kurulu'nun 2018 yılında öğretmen yetiştirme lisans programlarında yaptığı değişiklikle birlikte tüm programlarda "Açık ve Uzaktan Öğrenme" dersine yer verilmesi önemli bir adım olarak düşünülebilir.

3. Bu çalışma ile alan yazında yer alan çalışmalarda, uzaktan eğitime yönelik tutum ve eöğrenmeye hazır bulunuşluk üzerindeki etkililiği ile ilgili en tutarlı sonuçlara ulaşılan değişkenler teknolojik olanaklarla ilgili değişkenlerdir (bilgisayar, internet, akıllı telefon). Cinsiyet, yaş, bölüm, sınıf düzeyi ve deneyim değişkenleri ile ilgili ise çelişkili sonuçlar bulunmaktadır. Bu nedenle bu değişkenlerle ilgili olarak daha geniş evren üzerinde yürütülen, genelleyiciliği yüksek çalışmalara ihtiyaç duyulmaktadır.

\section{Etik Kurul Onay Bilgileri}

Bu çalışma, Kahramanmaraş Sütçü İmam Üniversitesi Sosyal ve Beşeri Bilimler Etik Kurulu'nun 12.06.2020 tarih ve 2020-16 sayılı kararı ile araştırma ve yayın etiğine uygun olarak gerçekleştirilmiştir.

\section{Kaynaklar}

Ağır, F. (2007). Uzaktan eğitime karşı tutum ölçeği geliştirmeye yönelik geçerlilik ve güvenirlik çalışması. e-Journal of New World Sciences Academy Social Sciences, 3(2), 128-139.

Akgün, F. (2015, Mayıs). Uzaktan eğitim ögrencilerinin web tabanlı ögretime yönelik tutumları ve çevrimiçi teknolojilere yönelik öz yeterlik algılarının incelenmesi. 9th International Computer \& Instructional Technologies Symposium'da (ICITS2015) sunulan bildiri, Afyon, Türkiye.

Aktaş, C. ve Çayc1, B. (2013). Yeni enformasyon ve iletişim teknolojilerinin sosyal hayattaki rolü. https://www.academia.edu/ adresinden 21 Haziran 2020 tarihinde erişilmiştir.

Alsancak-Sırakaya, D. ve Yurdugül, H. (2016). Öğretmen adaylarının çevrimiçi öğrenmeye hazır bulunuşluluk düzeylerinin incelenmesi. Ahi Evran Üniversitesi Kırşehir Eğitim Fakültesi Dergisi (KEFAD), 17(1), 185-200.

Ateş, A. ve Altun, E. (2008). Bilgisayar öğretmeni adaylarının uzaktan eğitime yönelik tutumlarının çeşitli değişkenler açısından incelenmesi. Gazi Eğitim Fakültesi Dergisi, $28(3), 125-145$.

Aypay, A. (2010). Information and communication technology usage and achivement of Turkish students in Pisa 2006. The Turkish Online Journal of Educational Technology - TOJET, 9(2), 116-124.

Barış, M. F. (2015). Üniversite öğrencilerinin uzaktan öğretime yönelik tutumlarının incelenmesi: Namık Kemal Üniversitesi örneği. Sakarya University Journal of Education, 5(2), 36-46.

Borotis, S. A., \& Poulymenakou, A. (2004), E-learning readiness components: Key issues to consider before adopting e-learning interventions. Proceedings of World Conference on E-Learning in Corporate, Government, Healthcare and Higher Education, Washington, DC, USA.

Chang, S. C., \& Tung, F. C. (2008). An empirical investigation of students' behavioural intentions to use the online learning course web sites. British Journal of EducationalTechnology, 39(1), 71-83.

Cohen, J. (1988). Statistical power analysis for the behavioral sciences (2nd ed). Hillsdale, NJ: Erlbaum.

Cohen, L. M., Manion, L., \& Morrison, K. (2007). Research methods in education. NY: Routledge.

Çetin, O. ve Güngör, B. (2014). İlköğretim öğretmenlerinin bilgisayar öz-yeterlik inançları ve bilgisayar destekli öğretime yönelik tutumları. Ondokuz Mayls Üniversitesi Ĕgitim Fakültesi Dergisi, 33(1), 55-78.

Çakır, Ö. ve Horzum, M. B. (2015). Öğretmen adaylarının çevrimiçi öğrenmeye hazır bulunuşluk düzeylerinin çeşitli değişkenler açısından incelenmesi. Eğitimde Kuram ve Uygulama, 11(1), 1-15. 
Çiftçi, S., Güneş, E., \& Üstündağ, M. T. (2010). Attitudes of distance education students towards web basedb learning - a casestudy. Procedia Socia land Behavioral Sciences, 2, 2393-2396.

Demir, Ö. (2015). Öğrencilerin ve öğretim elemanlarının e-ögrenmeye hazır bulunuşluk düzeylerinin incelenmesi: Hacettepe üniversitesi eğitim fakültesi örneği (Yayınlanmamış yüksek lisans tezi). Hacettepe Üniversitesi Eğitim Bilimleri Enstitüsü, Ankara.

Dikbaş, E. (2006). Öğretmen adaylarının e-öğrenmeye yönelik tutumlarının incelenmesi (Yayınlanmamış yüksek lisans tezi). Dokuz Eylül Üniversitesi Eğitim Bilimleri Enstitüsü, İzmir.

Durmuş, A. ve Bağcı, H. (2013). Öğretmen adaylarının web tabanlı öğretime yönelik tutumlarının farklı değişkenler açısından incelenmesi. Eğitim ve Öğretim Araştırmaları Dergisi, 2(4), 219-224.

Durmuş, A., \& Kaya, S. (2011). Computer and instructional technologies preservice teachers'attitudes regarding distance education. Procedia Social and Behavioral Sciences, 28, 661-666.

Göksu, H., ve Atmaca, S. (2019). Öğretmenlerin ve öğretmen adaylarının mobil eğitim uygulamalarına yönelik tutumları. Folklor/Edebiyat, 25(97), 105-115.

Gündüz, A. Y. (2013). Öğretmen adaylarının uzaktan eğitim algısı (Yayınlanmamış yüksek lisans tezi), Sakarya Üniversitesi Eğitim Bilimleri Enstitüsü, Sakarya.

Haznedar, Ö. (2012). Üniversite öğrencilerinin bilgi ve iletişim teknolojileri becerilerinin ve eögrenmeye yönelik tutumlarının farklı değişkenler açısından incelenmesi (Yayınlanmamış doktora tezi). Dokuz Eylül Üniversitesi Eğitim Bilimleri Enstitüsü, İzmir.

Hung, M. L., Chou, C., Chen, C. H., \& Own, Z. Y. (2010). Learner readiness for online learning: scale development and student perceptions. Computers \& Education, 55(3), 1080-1090. doi:10.1016/j.compedu.2010.05.004.

Horzum, F. (2019). Çevrimiçi öğrenmeye yönelik hazır bulunuşluk ile algılanan engeller arasındaki ilişkinin incelenmesi: Sakarya Üniversitesi pedagojik formasyon örneği. (Yayınlanmamış yüksek lisans tezi). Sakarya Üniversitesi Eğitim Bilimleri Enstitüsü, Sakarya.

Kabataş, S. (2019). Öğretmen adaylarının dijital vatandaşlık algılarının yaşam boyu öğrenme tutumları ve e-ögrenmeye hazır bulunuşluğu açısından değerlendirilmesi (Yayınlanmamış yüksek lisans tezi). Bartın Üniversitesi Eğitim Bilimleri Enstitüsü, Bartın.

Karaoğlan-Yılmaz, F. G. (2016, July). Examining self directed learning with technology based on different learning approaches. Paper presented at the International Academic Conference on Teaching, Learning and E-learning, Budapest, Hungary.

Karasar, N. (2012). Bilimsel araştırma yöntemi. Ankara: Nobel Yayıncılık.

Kaur, K., \& Abas, Z. W. (2004, July). An assessment of e-Learning readiness at the open university Malaysia. Paper presented at the international conference on computers in education (ICCE2004), Melbourne, Australia.

Kışla, T. (2005). Üniversite öğrencilerinin uzaktan eğitime yönelik tutumları. (Yayınlanmamış yüksek lisans tezi). Ege Üniversitesi, Sosyal Bilimler Enstitüsü, İzmir.

Milli Eğitim Bakanlığ1 [MEB] (2020, 19 Mart). Bakan Selçuk, 23 Mart'ta başlayacak uzaktan eğitime ilişkin detaylart anlatt. https://www.meb.gov.tr/bakan-selcuk-23-martta baslayacak-uzaktan-egitime-iliskin-detaylari-anlatti/haber/20554/tradresinden edinilmiştir.

Mercan, A. (2018). Üniversite ögrencilerinin uzaktan ĕgitim ile ilgili görüşleri ve hazır bulunuşluklart: Afyon Kocatepe Üniversitesi Fen Edebiyat Fakültesi örneği (Yayınlanmamış yüksek lisans tezi). Afyon Kocatepe Üniversitesi, Afyon.

Oral, B. (2017). Uzaktan eğitim. Ö. Demirel ve E. Altun (Ed.), Öğretim teknolojileri ve materyal tasarımı (ss. 143-180) içinde, Ankara: Pegem A Yayıncılık.

Özkul, A. E. ve Aydın, C. H. (2012, Şubat). Öğrenci adaylarının açık ve uzaktan ögrrenmeye yönelik görüşleri. XIV. Akademik Bilişim Konferansında sunulan bildiri, Uşak, Türkiye. 
Öztaş, S. ve Kılıç, B. (2017). Atatürk ilkeleri ve inkılâp tarihi dersinin uzaktan eğitim şeklinde verilmesinin öğrenci görüşleri açısından değerlendirilmesi. Turkish History Education Journal, 6(2), 268-293.

Persico, D., Manca, S., \& Pozzi, F. (2014). Adapting the technology acceptance model to evaluate the innovative potential of e-learning systems. Computers in Human Behavior, 30, 614622.

Sakal, M. (2017). Çevrimiçi öğrenmede öğrencilerin hazır bulunuşluk düzeylerinin demografik özelliklerine göre incelenmesi. Sosyal ve Beşeri Bilimler Araştırmaları Dergisi, 18(39), 81102.

Senemoğlu, N. (2009). Gelişim, öğrenme ve ögretim kuramdan uygulamaya (14. Baskı). Ankara: PegemA Akademi

Tabachnick, B. G., \& Fidell, L. S. (2007). Using multivariate statistics (Vol. 5). Boston, MA: Pearson.

Tavşanc1l, E. (2002). Tutumların ölçülmesi ve spss ile veri analizi (1. Bask1). Ankara: Nobel Yayınc1lik.

Tekinarslan, E. (2008). Attitudes of Turkish distance learners toward internet-basedlearning: an investigation depending on demographical characteristics. Turkish Online Journal of Distance Education-TOJDE, 9(1), 67-84.

Turgut, F. ve Baykul, Y. (2010). Eğitimde Ölçme ve Değerlendirme. Ankara: Pegem A Yayıncilik.

Yağc1, M., Alsancak-Sırakaya, D. A., \& Özüdoğru, G. (2015). The investigation of attitude and readiness of information and communication Technologies pre-service teachers toward web based learning. Procedia-Social and Behavioral Sciences, 174, 1099-1106.

Yavuzalp, N., Demirel, M., Taş, H. ve Canbolat, G. (2017). Türkiye'deki üniversitelerin uzaktan eğitim merkezlerinin mevcut durumu üzerine bir doküman analizi çalışması. Kastamonu Ĕ̈itim Dergisi, 25(2), 759-776.

Yenilmez, K., Turgut, M. ve Balbağ, M. Z. (2017). Öğretmen adaylarının uzaktan eğitime yönelik tutumlarının bazı değiş̧kenler açısından incelenmesi. Erzincan Üniversitesi Eğitim Fakültesi Dergisi, 19(2), 91-107.

Yıldız, S. (2016). Pedogojik formasyon eğitimi alan öğrencilerin uzaktan eğitime yönelik tutumları. Bolu Abant İzzet Baysal Üniversitesi Sosyal Bilimler Enstitüsü Dergisi, 16(1), 301-329.

Y1lmaz, R., Sezer, B. ve Yurdugül, H.(2019). Üniversite öğrencilerinin e-öğrenmeye hazır bulunuşluklarının incelenmesi: Bartın Üniversitesi örneği. Ege Eğitim Dergisi, 20(1), 180195.

Yurdakul, B. (2019). Uzaktan eğitim. Ö. Demirel (Ed.), Eğitimde yeni yönelimler (ss. 271-288) içinde. Ankara: Pegem A yayıncılık.

Yurdugül, H. ve Alsancak-Sırakaya, D. (2013). Çevrimiçi öğrenmeye hazır bulunuşluk ölçeği: Geçerlik ve güvenirlik çalışması. Eğitim ve Bilim, 38(169), 391-406.

Yurdugül, H. ve Demir, Ö. (2017). Öğretmen yetiştiren lisans programlarındaki öğretmen adaylarının e-öğrenmeye hazır bulunuşluklarının incelenmesi: Hacettepe üniversitesi örneği. Hacettepe Üniversitesi Eğitim Fakültesi Dergisi, 32(4), 896-915. doi:10.16986/HUJE.2016022763

Yüksek Öğretim Kurumu [YÖK] (2020, 18 Mart). YÖK Başkanı Saraç üniversitelerde verilecek olan uzaktan eğitime ilişkin açılama yaptı. https://www.yok.gov.tr/Sayfalar/Haberler/ 2020/universitelerde-uygulanacak-uzaktan-egitime-iliskin-aciklama.aspx adresinden edinilmiştir. 


\section{Introduction}

\section{Extended Abstract}

Due to the virus outbreak caused by novel coronavirus (Covid-19) that occurred on December 1, 2019 in Wuhan, China, the interruption of face-to-face education and the introduction of distance education services in many countries of the world, include Turkey once again demonstrated the importance of distance education activities. In this process, not only the institutions and educators are ready for distance education, but also the readiness of e-learning and the attitudes towards distance education for students attending formal education with traditional face-to-face education approaches will determine the effectiveness and efficiency of the process. It is attempted to contribute to the literature by examining these two variables, which have been limited in number, until now with a broad perspective. In this study, it was aimed to investigate the distance education attitudes and readiness of e-learning of Kahramanmaraş Sütçü İmam University (KSU) education faculty students according to different variables. For this purpose, answers to the following questions were sought:

1. What are the levels of students' attitudes towards distance education and their readiness for e-learning?

2. Do students' attitudes towards distance education and e-learning availability differ according to gender, age, grade, department, computer, internet, and smartphone experience variables?

3. Is there a significant relationship between students' attitudes towards distance education and their readiness to learn?

\section{Method}

Descriptive scanning method was used in the research. The participants of the research are 333 students enrolled in 7 different programs in the Faculty of Education at Kahramanmaraş Sütçü Imam University in the spring term of the 2019-2020 academic year. In the research, online measurement tool consisting of 3 parts was used as data collection tool. In the first part of the measurement tool, there is demographic information form, in the second part, the e-learning readiness (ELR) scale developed by Yurdugül and Demir (2017) was used in the second part and the attitude scale against distance education developed by Ağır (2007) was used in the last part. Kruskall Wallis and Mann Whitney U statistics, which are nonparametric statistical methods, were used for the department, which contains a small number of individuals, according to the subdimensions found in the scale of the ELR scale, since normal distribution assumptions could not be met in age and smartphone variables. It was observed that the assumptions of normal distribution were also met in the subgroups of other variables, and whether the scale scores changed according to these variables was analyzed with the independent samples $t$ test and ANOVA. The differences seen according to the variables are reported with their effect sizes. In addition, Pearson correlation coefficient was used to analyze the relationship between scales.

\section{Results and Discussion}

It was observed that the attitudes of the participants towards distance education were close to the undecided level. It was observed that the students' ELR levels were at a moderate level. According to the sub-dimensions of the ELR scale, the readiness levels of the students were found to be high in internet self-efficacy, learner control and self-learning dimensions, and in the computer selfefficacy and online communication self-efficacy dimensions, the level of motivation for elearning was low. In the analysis, it has been found that the e-learning readiness and attitudes of the students who have computers and internet connection are at a higher level. It was observed that students' e-learning readiness and attitudes differ according to the grade variable. It was found that their attitudes towards distance education also differed according to the departmental variable. In addition, it is determined that students who have a smartphone and have similar distance education experience are more likely to be ready for e-learning. According to another result of the research, there is a moderate relationship between attitude towards distance education and readiness to e-learning. In terms of the sub-dimensions of the e-learning readiness structure, 
a high level of relation was found between the attitude towards distance education and the motivation dimension.

When the findings obtained are examined with the literature, one of the remarkable results is that students' readiness to e-learning is more acceptable than their attitudes, as seen in this study. The fact that the highest readiness of students' in internet self-efficacy can be explained by the time they have spent on the internet and the experience they have gained. On the other hand, the fact that the lowest readiness is seen in motivation can be explained by the fact that students feel more prone to face-to-face education. It was observed that the grade differentiation from the grade, the department, computer and internet variables determined to be effective on the attitude towards distance education is not regular, and the difference in the part variable is not related to the skill area (numerical, verbal, language), which are the main features of the divisions. Deeper research is needed. It is evaluated that students with computers, internet, smart phones and experience have high readiness for e-learning and these findings are in line with the literature and expectations. Among these variables, computer and internet have also been shown to be effective in their attitude towards distance education. The lower attitudes of students who do not have the necessary infrastructure for distance education may be due to the lack of conditions for these students. The fact that there is a moderate relationship between attitude towards distance education and readiness to e-learning shows that these two features have in common. 